\title{
Synthesis of the Core Structure of Daphnimacropodines
}

\author{
Yuye Chen, ${ }^{\dagger, \downarrow}, / /$ Jingping $\mathrm{Hu},{ }^{\dagger},,, / /$ Lian-Dong Guo, ${ }^{\dagger}$ Peilin Tian, ${ }^{\dagger}$ Tianyue $\mathrm{Xu}^{\dagger}$ and \\ Jing $\mathrm{Xu}^{\dagger, *}$ \\ $\dagger$ Department of Chemistry and Shenzhen Grubbs Institute, Southern University of \\ Science and Technology, Shenzhen, Guangdong, China \\ $\$$ State Key Laboratory of Quality Research in Chinese Medicine, Institute of Chinese \\ Medical Sciences, University of Macau, China \\ $\S$ School of Chemistry and Chemical Engineering, Harbin Institute of Technology, \\ Harbin, Heilongjiang, China
}

xuj@sustech.edu.cn

Supporting information

Table of Contents

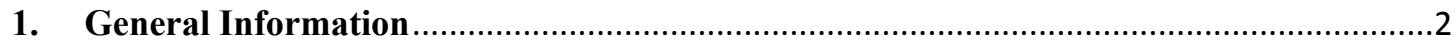

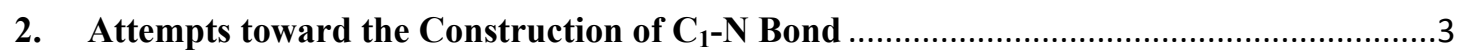

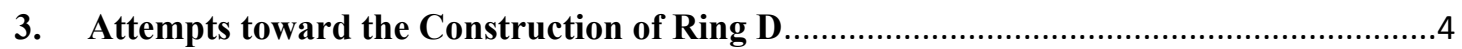

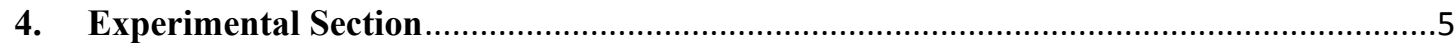

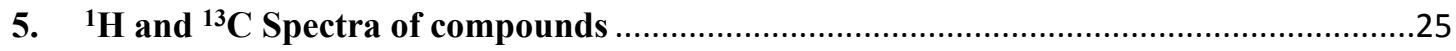




\section{General Information}

Unless otherwise mentioned, all reactions were carried out under argon atmosphere and anhydrous conditions. Tetrahydrofuran (THF) was distilled from sodium-benzophenone under argon atmosphere. Dichloromethane (DCM) and acetonitrile were distilled from calcium hydride. Reactions were monitored by TLC (GF254) supplied by Yantai Chemicals (China) visualized by UV or stained with ethanolic solution of phosphomolybdic acid, cerium sulfate, basic solution of $\mathrm{KMnO}_{4}$, or iodine. Flash column chromatography was performed using silica gel (particle size 0.040-0.063 mm). NMR spectra were recorded on Bruker AV400 MHz or Bruker AV500 MHz instruments and calibrated by using residual undeuterated chloroform in $\mathrm{CDCl}_{3}(\delta \mathrm{H}=7.26 \mathrm{ppm}$, $\delta \mathrm{C}=77.16 \mathrm{ppm})$ or $\mathrm{CD}_{2} \mathrm{Cl}_{2}(\delta \mathrm{H}=5.32 \mathrm{ppm}, \delta \mathrm{C}=53.84 \mathrm{ppm})$ as internal references. The following abbreviations were used to explain the multiplicities: $\mathrm{s}=$ singlet, brs $=$ broad singlet, $\mathrm{d}=$ doublet, $\mathrm{t}=$ triplet, $\mathrm{q}=$ quartet, $\mathrm{dd}=$ double doublet, $\mathrm{dt}=$ double triplet, $\mathrm{td}=$ triple doublet, $\mathrm{ddd}=$ doublet of double doublet, $\mathrm{m}=$ multiplet. High-resolution mass spectra (HRMS) were recorded on a Thermo ScientificTM Q-exactive hybrid quadrupole-orbitrap mass spectrometer. 


\section{Attempts toward the Construction of $\mathrm{C}_{1}-\mathrm{N}$ Bond}

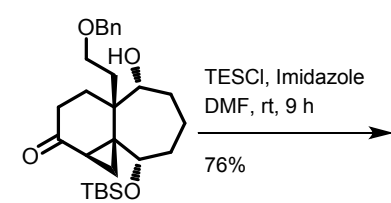

7

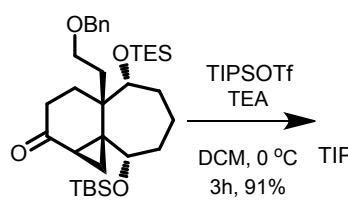

S1

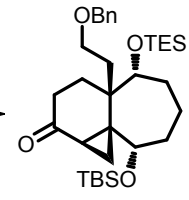

S1

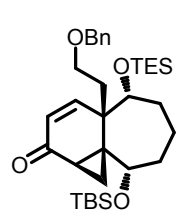

s2

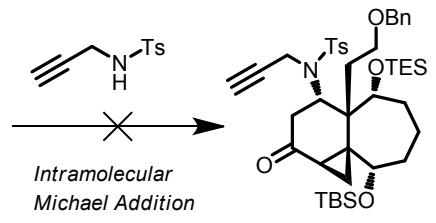

S3

Scheme S1. Attempts toward the construction of $\mathrm{C}_{1}-\mathrm{N}$ bond.

With 7 in hand, the next challenge we faced was elaboration of the $\mathrm{C}_{1}-\mathrm{N}$ bond construction (Scheme S1). Treatment of 7 with chlorotriethylsilane afforded S1, which underwent a Saegusa-Ito oxidation to give enone S2. Unfortunately, intermolecular aza-Michael addition failed to give the desired product. Then we explored the direct $\beta$-azido functionalization of triisopropylsilyl enol ethers in the presence of iodosobenzene and trimethylsilyl azide, ${ }^{1}$ interestingly, only $\alpha, \beta$-unsaturated ketone $\mathbf{S 2}$ was observed in this case.

1. Magnus, P.; Lacour, J. J. Am. Chem. Soc. 1992, 114, 767. 


\section{Attempts toward the Construction of Ring D}
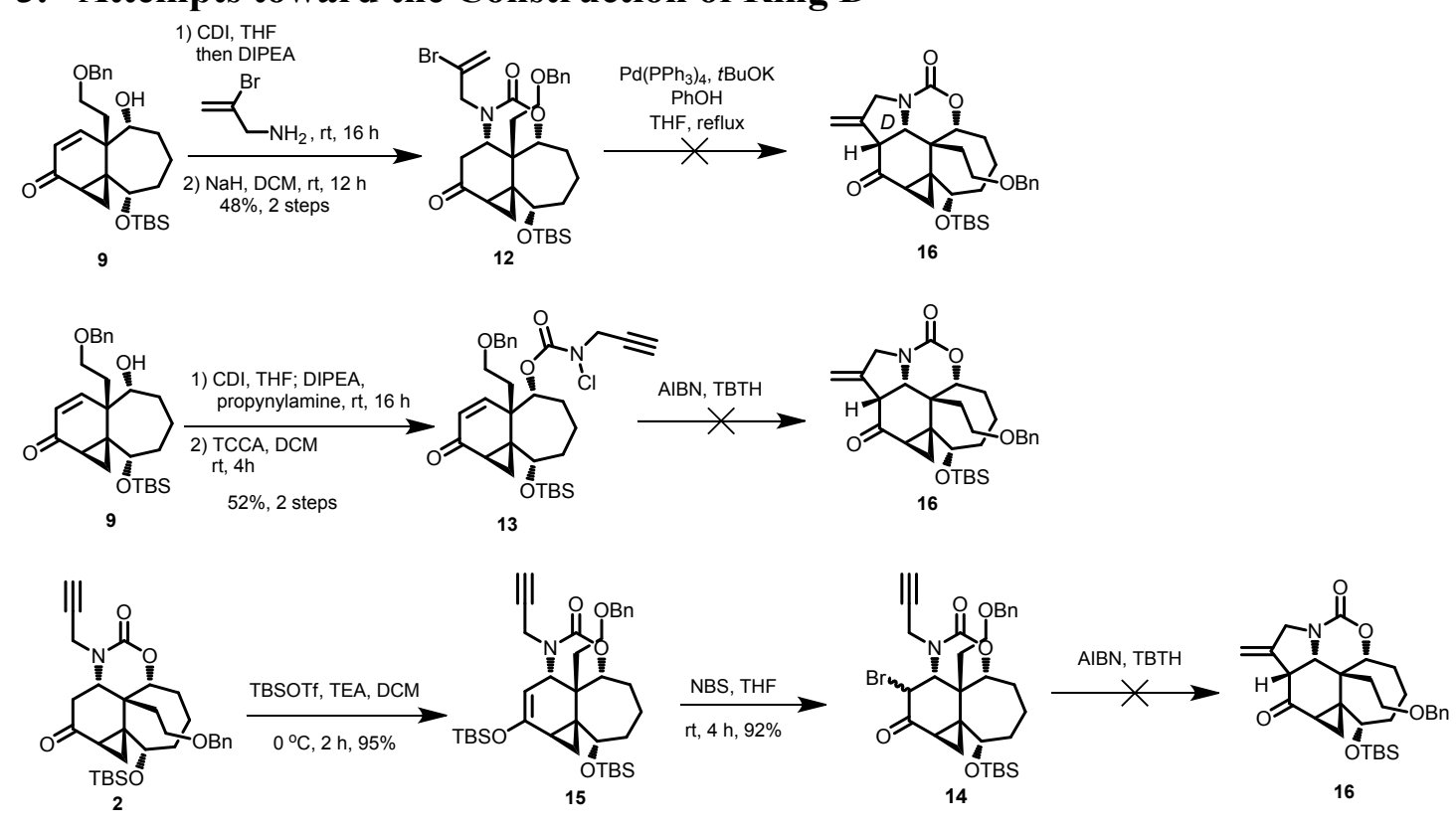

Scheme S2. Attempts toward the construction of ring D.

In 2005, Bonjoch and his co-workers reported the synthesis of ABC ring system of the Daphniphyllum alkaloid calyciphylline A. ${ }^{2}$ They constructed the nitrogen contained bridged ring with a novel palladium-catalyzed intramolecular cyclization reaction. In order to verify that whether Bonjoch's strategy is applicable in our case, compound 9 was treated with CDI, N-ethyldiisopropylamine (DIPEA) and 2-bromoprop-2-en-1-amine, followed an intramolecular aza-Michael addition to give the precursor 12. Unfortunately, treatment with $\mathbf{1 2}$ under standard conditions failed to give the desired product $\mathbf{1 6}$.

In 2014, Stockdill et al. reported the synthesis of a tricyclic core of calyciphylline A, the key reaction was a cascade radical reaction. ${ }^{3}$ Inspired by Stockdill's work, we treated compound 9 with CDI, DIPEA and propynylamine, followed by the treatment with trichloroisocyanuric acid (TCCA) in DCM afforded the propargyl chloroamine derivative substrate 13. However, treatment of $\mathbf{1 3}$ under standard radical cyclization condition failed to give the desired product $\mathbf{1 6}$.

To further study whether radical cyclization ${ }^{4}$ can be applied in our case, compound 2 was transformed to silyl enol ether 15, which was brominated with $N$-Bromosuccinimide (NBS) in THF to afford the radical cyclization precursor 14. However, treatment of $\mathbf{1 4}$ under standard radical cyclization condition failed to give the desired product $\mathbf{1 6}$, only very messy results observed.

2. Solé, D.; Urbaneja, X.; Bonjoch, J. Org. Lett. 2005, 7, 5461.

3. Ibrahim, A. A.; Golonka, A. N.; Lopez, A. M.; Stockdill, J. L. Org. Lett. 2014, 16, 1072.

4. For selected reviews, see: (a) Jasperse, C. P.; Curran, D. P.; Fevig, T. L. Chem. Rev. 1991, 91, 1237. (b) Giese, B.; Kopping, B.; Göbel, T.; Dickhaut, J.; Thoma, G.; Kulicke, K. J.; Trach, F. Org. React. 1996, 48, 301. (c) Romero, K. J.; Galliher, M. S.; Pratt, D. A.; Stephenson, C. R. J. Chem. Soc. Rev. 2018, 47, 7851. For selected examples, see: (d) Schinzer, D.; Jones, P. G.; Obierey, K. Tetrahedron Lett. 1994, 35, 5853. (e) Jiang, C.-H.; Bhattacharyya, A.; Sha, C.-K. Org. Lett. 2007, 9, 3241. (f) MacDonald, F. K.; Burnell, D. J. J. Org. Chem. 2009, 74, 6973. (g) Chen, C.-H.; Chen, Y.-K.; Sha, C.-K. Org. Lett. 2010, 12, 1377. 


\section{Experimental Section Preparation of Compound S6}<smiles>O=C1CCCCC(=O)C1</smiles>

4

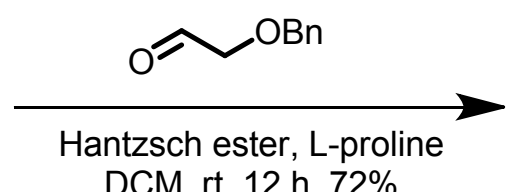
DCM, rt, 12 h, $72 \%$

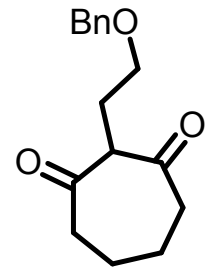

S6

To a stirred solution of cycloheptane-1,3-dione 4 (5.1 g, 0.04 mol), 2-(benzyloxy)acetaldehyde (18.0 g, $0.12 \mathrm{~mol})$ and Hantzsch ester $(12.7 \mathrm{~g}, 0.05 \mathrm{~mol})$ in $\mathrm{CH}_{2} \mathrm{Cl}_{2}(50 \mathrm{~mL})$ at room temperature was added L-proline $(0.9 \mathrm{~g}, 7.8 \mathrm{mmol})$. The resulting mixture was stirred for 12 hours at room temperature before being concentrated in vacuo. The resulting suspension was filtered, washed with $\mathrm{Et}_{2} \mathrm{O}$ and dried in vacuo. At last, the residue was purified by column chromatography (30:1 $\mathrm{PE} / \mathrm{EtOAc})$ to give the $\mathbf{S 6}(7.5 \mathrm{~g}, 72 \%)$ as colorless oil.

${ }^{1} \mathbf{H}$ NMR $\left(400 \mathrm{MHz}, \mathrm{CDCl}_{3}\right) \delta 7.39-7.26(\mathrm{~m}, 5 \mathrm{H}), 4.42(\mathrm{~s}, 2 \mathrm{H}), 4.10(\mathrm{t}, J=6.8 \mathrm{~Hz}$, $1 \mathrm{H}), 3.45(\mathrm{t}, J=5.9 \mathrm{~Hz}, 2 \mathrm{H}), 2.61-2.42(\mathrm{~m}, 4 \mathrm{H}), 2.18-2.01(\mathrm{~m}, 4 \mathrm{H}), 1.87-1.78$ $(\mathrm{m}, 2 \mathrm{H})$.

${ }^{13}$ C NMR $\left(100 \mathrm{MHz}, \mathrm{CDCl}_{3}\right) \delta 206.5,138.4,128.5,127.9,127.8,73.0,67.6,63.5$, 44.3, 26.5, 25.4.

HRMS (ES+) exact mass calculated for $[\mathrm{M}+\mathrm{H}]^{+}\left(\mathrm{C}_{16} \mathrm{H}_{21} \mathrm{O}_{3}{ }^{+}\right)$requires $\mathrm{m} / \mathrm{z}: 261.1485$, found $\mathrm{m} / \mathrm{z}: 261.1484$. 


\section{Preparation of Compound 3}

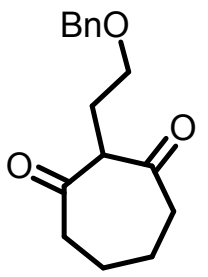

S6
MVK, TEA, rt, $18 \mathrm{~h}$

then rac-proline, DMSO

$80^{\circ} \mathrm{C}, 16 \mathrm{~h}$

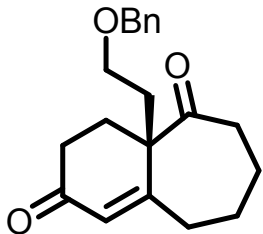

3

To a stirred solution of S6 (7.2 g, $27.7 \mathrm{mmol})$ in MVK (11.6 g, $166.2 \mathrm{mmol})$ was added TEA $(0.28 \mathrm{~g}, 2.80 \mathrm{mmol})$. The resulting mixture was stirred at room temperature for 18 hours before being concentrated in vacuo. The residue was dissolved in DMSO $(100 \mathrm{~mL})$ and followed rac-proline (1.6 g, $0.014 \mathrm{~mol})$. This solution was warmed to $80{ }^{\circ} \mathrm{C}$ for 16 hours before it was cooled down to room temperature and quenched with water. The mixture was extracted with EtOAc, dried over $\mathrm{Na}_{2} \mathrm{SO}_{4}$ and concentrated in vacuo. At last, the residue was purified by column chromatography (10:1 PE/EtOAc) to give $3(5.9 \mathrm{~g}, 69 \%)$ as pale-yellow oil.

${ }^{1} \mathbf{H}$ NMR $\left(400 \mathrm{MHz}, \mathrm{CDCl}_{3}\right) \delta 7.36-7.26(\mathrm{~m}, 5 \mathrm{H}), 6.07(\mathrm{~s}, 1 \mathrm{H}), 4.49-4.41(\mathrm{~m}, 2 \mathrm{H})$, $3.68-3.59(\mathrm{~m}, 2 \mathrm{H}), 2.70-2.59(\mathrm{~m}, 2 \mathrm{H}), 2.52-2.33(\mathrm{~m}, 3 \mathrm{H}), 2.24-2.17(\mathrm{~m}, 2 \mathrm{H})$, $2.10-2.03(\mathrm{~m}, 2 \mathrm{H}), 1.99-1.90(\mathrm{~m}, 3 \mathrm{H}), 1.62-1.45(\mathrm{~m}, 2 \mathrm{H})$.

${ }^{13} \mathrm{C}$ NMR $\left(100 \mathrm{MHz}, \mathrm{CDCl}_{3}\right) \delta 212.7,198.2,166.4,138.2,129.6,128.5,127.8$, 127.7, 73.1, 67.3, 55.0, 40.9, 36.1, 34.1, 33.3, 31.7, 30.7, 27.3.

HRMS (ES+) exact mass calculated for $[\mathrm{M}+\mathrm{H}]^{+}\left(\mathrm{C}_{20} \mathrm{H}_{25} \mathrm{O}_{3}{ }^{+}\right)$requires $\mathrm{m} / \mathrm{z}: 313.1798$, found $\mathrm{m} / \mathrm{z}: 313.1794$. 


\section{Preparation of Compound S7}<smiles>O=C1C=C2CCCCC(=O)C2(CCOc2ccccc2)CC1</smiles>

3

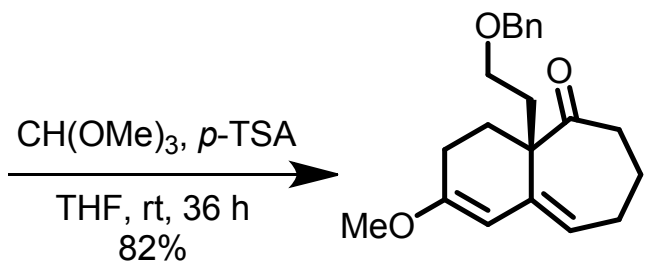

S7

To a stirred solution of $3(12.5 \mathrm{~g}, 0.04 \mathrm{~mol})$ in THF $(120 \mathrm{~mL})$ was added trimethoxymethane $(42.4 \mathrm{~g}, 0.40 \mathrm{~mol})$ and $p$-toluenesulfonic acid monohydrate $(0.76$ $\mathrm{g}, 4.00 \mathrm{mmol})$. This solution was stirred at room temperature for 36 hours before it was quenched with TEA and saturated $\mathrm{NaHCO}_{3}$ solution. The mixture was extracted with EtOAc, washed with brine, dried over $\mathrm{Na}_{2} \mathrm{SO}_{4}$ and concentrated in vacuo. At last, the residue was purified by column chromatography (50:1:1 PE/EtOAc/TEA) to give S7 (10.7 g, 82\%) as pale-yellow oil.

${ }^{1} \mathbf{H}$ NMR $\left(400 \mathrm{MHz}, \mathrm{CDCl}_{3}\right) \delta 7.31(\mathrm{t}, J=2.8 \mathrm{~Hz}, 5 \mathrm{H}), 5.54(\mathrm{t}, J=7.4 \mathrm{~Hz}, 1 \mathrm{H}), 5.26$ (s, 1H), $4.47(\mathrm{~s}, 2 \mathrm{H}), 3.72-3.65(\mathrm{~m}, 1 \mathrm{H}), 3.59(\mathrm{~s}, 3 \mathrm{H}), 3.53-3.47(\mathrm{~m}, 1 \mathrm{H}), 2.98-$ $2.90(\mathrm{~m}, 1 \mathrm{H}), 2.42-2.34(\mathrm{~m}, 1 \mathrm{H}), 2.25-1.79(\mathrm{~m}, 9 \mathrm{H}), 1.51(\mathrm{dd}, J=12.9,5.3 \mathrm{~Hz}$, $1 \mathrm{H})$.

${ }^{13}$ C NMR $\left(100 \mathrm{MHz}, \mathrm{CDCl}_{3}\right) \delta 216.4,155.7,138.7,138.2,128.5,127.8,127.6$, 121.3, 99.4, 73.1, 67.3, 54.5, 54.1, 37.0, 31.9, 31.4, 26.6, 24.2, 24.1.

HRMS (ES+) exact mass calculated for $[\mathrm{M}+\mathrm{H}]^{+}\left(\mathrm{C}_{21} \mathrm{H}_{27} \mathrm{O}_{3}{ }^{+}\right)$requires $\mathrm{m} / \mathrm{z}: 327.1955$, found $\mathrm{m} / \mathrm{z}: 327.1953$. 


\section{Preparation of Compound S8}<smiles>COC1=CC2=CCCCC(=O)C2(CCOc2ccccc2)CC1</smiles>

S7
1) $\mathrm{NaBH}_{4}, \mathrm{MeOH}$

$\mathrm{rt}, 12 \mathrm{~h}$

2) Oxone, $\mathrm{NaHCO}_{3}$ $\mathrm{THF} / \mathrm{H}_{2} \mathrm{O}, 0^{\circ} \mathrm{C}, 4 \mathrm{~h}$

$77 \%, 2$ steps<smiles>O=C1C=C2[C@H](O)CCC[C@H](O)[C@]2(CCOc2ccccc2)CC1</smiles>

S8

To a stirred solution of $\mathbf{S} 7(2.1 \mathrm{~g}, 6.5 \mathrm{mmol})$ in $\mathrm{MeOH}(20 \mathrm{~mL})$ at $0{ }^{\circ} \mathrm{C}$ was added sodium borohydride $(0.5 \mathrm{~g}, 13.2 \mathrm{mmol})$ in portions. The reaction mixture was then warmed up to room temperature and stirred for 12 hours. The reaction was quenched with acetone and concentrated in vacuo. The residue was dissolved in EtOAc, washed with saturated $\mathrm{NaHCO}_{3}$ solution and brine, dried over $\mathrm{Na}_{2} \mathrm{SO}_{4}$ and concentrated in vacuo. The crude sec-alcohol was used in the next step without further purification.

An ice-cooled heterogeneous solution of sec-alcohol (assuming $6.5 \mathrm{mmol}$ ), THF (120 $\mathrm{mL}), \mathrm{H}_{2} \mathrm{O}(20 \mathrm{~mL})$ and $\mathrm{NaHCO}_{3}(2.2 \mathrm{~g}, 25.96 \mathrm{mmol})$ was treated with oxone $(8.0 \mathrm{~g}$, $13.0 \mathrm{mmol})$ in $\mathrm{H}_{2} \mathrm{O}(60 \mathrm{~mL})$ dropwise. The reaction mixture was stirred at the same temperature for 2 hours. The reaction was quenched with saturated $\mathrm{NaS}_{2} \mathrm{O}_{3}$ solution and extracted with EtOAc. The combined extract was washed with water and brine, dried over $\mathrm{Na}_{2} \mathrm{SO}_{4}$ and concentrated in vacuo. At last, the residue was purified by column chromatography $(2: 1 \mathrm{PE} / \mathrm{EtOAc})$ to give $\mathbf{S 8}(1.65 \mathrm{~g}, 77 \%$ over 2 steps $)$ as colorless oil.

${ }^{1} \mathbf{H}$ NMR $\left(400 \mathrm{MHz}, \mathrm{CDCl}_{3}\right) \delta 7.39-7.28(\mathrm{~m}, 5 \mathrm{H}), 6.32(\mathrm{~s}, 1 \mathrm{H}), 4.53(\mathrm{~s}, 2 \mathrm{H}), 4.28$ (d, $J=10.8 \mathrm{~Hz}, 1 \mathrm{H}), 4.04$ (brs, $1 \mathrm{H}), 3.83(\mathrm{~s}, 1 \mathrm{H}), 3.73$ (t, $J=10.1 \mathrm{~Hz}, 1 \mathrm{H}), 3.68-$ 3.58 (m, 1H), 2.89 (brs, 1H), $2.58-2.25$ (m, 2H), $2.20-2.07$ (m, 3H), $2.02-1.84(\mathrm{~m}$, 2H), $1.81-1.74(\mathrm{~m}, 1 \mathrm{H}), 1.58(\mathrm{~s}, 3 \mathrm{H}), 1.47-1.36(\mathrm{~m}, 1 \mathrm{H})$.

${ }^{13} \mathrm{C}$ NMR $\left(100 \mathrm{MHz}, \mathrm{CDCl}_{3}\right) \delta 199.7,176.3,136.5,128.6,128.2,127.9,124.0,76.6$, 73.5, 69.6, 67.0, 44.1, 39.6, 37.0, 33.1, 32.4, 24.6, 24.4.

HRMS (ES+) exact mass calculated for $[\mathrm{M}+\mathrm{H}]^{+}\left(\mathrm{C}_{20} \mathrm{H}_{27} \mathrm{O}_{4}{ }^{+}\right)$requires m/z: 331.1904, found $\mathrm{m} / \mathrm{z}: 331.1900$. 


\section{Preparation of Compound 5}<smiles>O=C1C=C2[C@@H](O)CCC[C@H](O)C2(CCOc2ccccc2)CC1</smiles>

S8

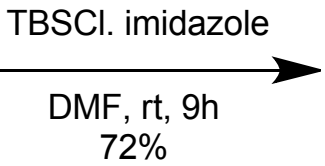

$72 \%$

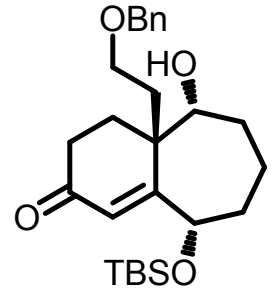

5

To a solution of $\mathbf{S 8}$ (1.94 g, $5.88 \mathrm{mmol})$ and imidazole (0.72 $\mathrm{g}, 10.56 \mathrm{mmol})$ in DMF $(25 \mathrm{~mL})$ was added tert-butyldimethlsilylchloride $(1.59 \mathrm{~g}, 10.56 \mathrm{mmol})$ in one portion. The mixture was stirred at room temperature for 9 hours. The reaction was quenched with saturated $\mathrm{NaHCO}_{3}$ solution and extracted with EtOAc. The combined extract was washed with water and brine, dried over $\mathrm{Na}_{2} \mathrm{SO}_{4}$ and concentrated in vacuo. At last, the residue was purified by column chromatography (10:1 PE/EtOAc) to give $5(1.88 \mathrm{~g}, 72 \%)$ as colorless oil.

${ }^{1} \mathbf{H}$ NMR $\left(500 \mathrm{MHz}, \mathrm{CDCl}_{3}\right) \delta 7.36-7.28(\mathrm{~m}, 5 \mathrm{H}), 6.31(\mathrm{~s}, 1 \mathrm{H}), 4.54(\mathrm{~s}, 2 \mathrm{H}), 4.38$ $(\mathrm{d}, J=3.3 \mathrm{~Hz}, 1 \mathrm{H}), 4.21(\mathrm{dd}, J=10.3,3.2 \mathrm{~Hz}, 1 \mathrm{H}), 3.77-3.63(\mathrm{~m}, 3 \mathrm{H}), 2.40(\mathrm{dd}, J=$ 17.2, $3.5 \mathrm{~Hz}, 1 \mathrm{H}), 2.33-2.18(\mathrm{~m}, 2 \mathrm{H}), 2.10-2.03(\mathrm{~m}, 1 \mathrm{H}), 1.97-1.84(\mathrm{~m}, 2 \mathrm{H}), 1.76$ $-1.69(\mathrm{~m}, 1 \mathrm{H}), 1.59-1.45(\mathrm{~m}, 4 \mathrm{H}), 0.84(\mathrm{~s}, 9 \mathrm{H}), 0.02(\mathrm{~d}, J=1.1 \mathrm{~Hz}, 3 \mathrm{H}),-0.03$ (d, $J$ $=1.2 \mathrm{~Hz}, 3 \mathrm{H})$.

${ }^{13}$ C NMR $\left(100 \mathrm{MHz}, \mathrm{CDCl}_{3}\right) \delta 199.6,175.6,136.5,128.9,128.6,128.3,124.9,77.4$, 74.1, 70.4, 67.3, 44.7, 41.7, 38.4, 33.5, 32.4, 25.8, 24.6, 24.4, 18.1, -4.5, -4.6.

HRMS (ES+) exact mass calculated for $[\mathrm{M}+\mathrm{H}]^{+}\left(\mathrm{C}_{26} \mathrm{H}_{41} \mathrm{O}_{4} \mathrm{Si}^{+}\right)$requires $\mathrm{m} / \mathrm{z}$ : 445.2769, found $\mathrm{m} / \mathrm{z}$ : 445.2768 . 


\section{Preparation of Compound S9}<smiles>O=C1C=C2[C@H](O[13C](F)(F)F)CCC[C@H](O)[C@]2(CCOc2ccccc2)CC1</smiles>

5

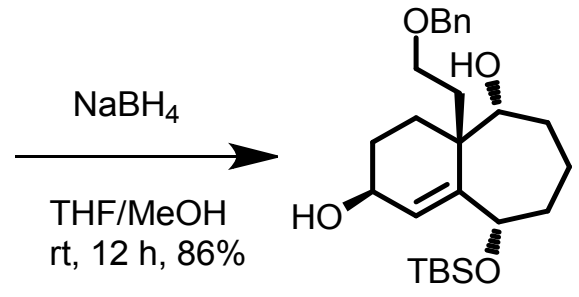

S9

To an argon-purged stirred solution of 5 (7.84 g, $17.62 \mathrm{mmol})$ in THF (150 mL) and $\mathrm{MeOH}(20 \mathrm{~mL})$ at $0{ }^{\circ} \mathrm{C}$ was added sodium borohydride $(2.67 \mathrm{~g}, 70.48 \mathrm{mmol})$ in portions. The reaction mixture was then warmed up to room temperature and stirred for 12 hours. The reaction was quenched with acetone and concentrated in vacuo. The residue was dissolved in EtOAc, washed with saturated $\mathrm{NaHCO}_{3}$ solution and brine, dried over $\mathrm{Na}_{2} \mathrm{SO}_{4}$ and concentrated in vacuo. At last, the residue was purified by column chromatography (5:1 PE/EtOAc) to give $\mathbf{S 9}(6.77 \mathrm{~g}, 86 \%)$ as colorless oil.

${ }^{1} \mathbf{H}$ NMR $\left(400 \mathrm{MHz}, \mathrm{CDCl}_{3}\right) \delta 7.38-7.29(\mathrm{~m}, 5 \mathrm{H}), 5.88(\mathrm{~s}, 1 \mathrm{H}), 4.54(\mathrm{~s}, 2 \mathrm{H}), 4.33(\mathrm{~s}$, $1 \mathrm{H}), 4.24(\mathrm{t}, J=7.6 \mathrm{~Hz}, 1 \mathrm{H}), 4.01(\mathrm{dd}, J=10.4,3.0 \mathrm{~Hz}, 1 \mathrm{H}), 3.72-3.55(\mathrm{~m}, 3 \mathrm{H})$, $2.07-2.00(\mathrm{~m}, 2 \mathrm{H}), 1.96-1.90(\mathrm{~m}, 2 \mathrm{H}), 1.80-1.67(\mathrm{~m}, 2 \mathrm{H}), 1.49-1.42(\mathrm{~m}, 3 \mathrm{H})$, $1.39-1.30(\mathrm{~m}, 2 \mathrm{H}), 0.87(\mathrm{~s}, 9 \mathrm{H}), 0.03(\mathrm{~s}, 3 \mathrm{H}), 0.00(\mathrm{~s}, 3 \mathrm{H})$.

${ }^{13}$ C NMR $\left(100 \mathrm{MHz}, \mathrm{CDCl}_{3}\right) \delta 151.8,136.9,128.8,128.3,128.2,126.2,79.1,73.8$, $70.2,68.1,66.8,43.3,42.5,39.7,32.1,28.2,25.9,24.9,23.5,18.1,-4.3,-4.6$.

HRMS (ES+) exact mass calculated for $[\mathrm{M}+\mathrm{Na}]^{+}\left(\mathrm{C}_{26} \mathrm{H}_{42} \mathrm{O}_{4} \mathrm{SiNa}^{+}\right)$requires $\mathrm{m} / \mathrm{z}$ : 469.2745, found $\mathrm{m} / \mathrm{z}: 469.2752$. 


\section{Preparation of Compound 6}<smiles>O[C@H]1CCC[C@@]2(CCOc3ccccc3)C1=C[C@H](O)CC[C@H]2O</smiles>

S9

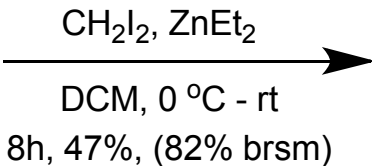

$8 \mathrm{~h}, 47 \%$, (82\% brsm)

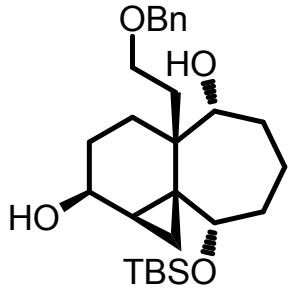

6

To an argon-purged stirred solution of diethylzinc $(22.2 \mathrm{~mL}, 1.0 \mathrm{M}$ solution in hexane, $22.2 \mathrm{mmol})$ in DCM $(60 \mathrm{~mL})$ at $0{ }^{\circ} \mathrm{C}$ was added diiodomethane $(11.9 \mathrm{~g}, 44.3$ mmol). The reaction mixture was stirred at the same temperature for $10 \mathrm{~min}$. Then a solution of S9 $(3.9 \mathrm{~g}, 8.8 \mathrm{mmol})$ in DCM $(60 \mathrm{~mL})$ was added into the solution dropwise. The reaction mixture was then warmed up to room temperature and stirred for 8 hours. The reaction was quenched with saturated $\mathrm{NH}_{4} \mathrm{Cl}$ solution and extracted with $\mathrm{Et}_{2} \mathrm{O}$. The combined extract was washed with brine, dried over $\mathrm{Na}_{2} \mathrm{SO}_{4}$ and concentrated in vacuo. At last, the residue was purified by column chromatography (3:1 PE/EtOAc) to give 6 (1.9 g, 47\%) as colorless oil and $\mathbf{S 9}(1.38 \mathrm{~g}, 35 \%)$.

${ }^{1}$ H-NMR (400 MHz, $\left.\mathrm{CDCl}_{3}\right) \delta: 7.44-7.03(\mathrm{~m}, 5 \mathrm{H}), 4.42(\mathrm{~s}, 2 \mathrm{H}), 4.10-4.05(\mathrm{~m}$, $1 \mathrm{H}), 3.48-3.39(\mathrm{~m}, 3 \mathrm{H}), 2.93(\mathrm{~s}, 1 \mathrm{H}), 1.82-1.56(\mathrm{~m}, 9 \mathrm{H}), 1.48-1.32(\mathrm{~m}, 1 \mathrm{H}), 1.22$ $-1.13(\mathrm{~m}, 2 \mathrm{H}), 1.00-0.89(\mathrm{~m}, 1 \mathrm{H}), 0.85(\mathrm{~s}, 9 \mathrm{H}), 0.73-0.32(\mathrm{~m}, 2 \mathrm{H}),-0.02(\mathrm{~d}, J=$ $3.9 \mathrm{~Hz}, 6 \mathrm{H})$.

${ }^{13}$ C-NMR $\left(100 \mathrm{MHz}, \mathrm{CDCl}_{3}\right) \delta: 138.1,128.5,127.7,127.7,77.3,75.6,73.3,68.2$, 67.0, 41.2, 37.0, 36.7, 33.7, 31.5, 29.7, 26.6, 25.9, 25.7, 18.1, 17.7, 12.4, -4.4, -5.0.

HRMS (ES+) exact mass calculated for $[\mathrm{M}+\mathrm{H}]^{+}\left(\mathrm{C}_{27} \mathrm{H}_{45} \mathrm{O}_{4} \mathrm{Si}^{+}\right)$requires $\mathrm{m} / \mathrm{z}$ : 461.3082, found m/z: 461.3080 . 
Preparation of Compound 7

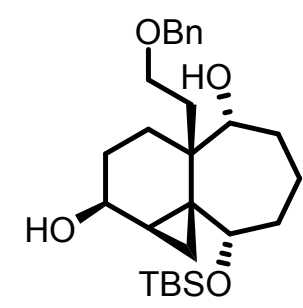

6

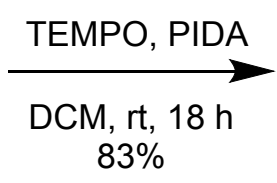

$83 \%$

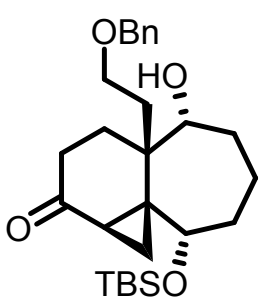

7

To a stirred solution of $6(920 \mathrm{mg}, 2.0 \mathrm{mmol})$ in DCM $(13 \mathrm{~mL})$ were added TEMPO (32 $\mathrm{mg}, 0.20 \mathrm{mmol})$ and $\mathrm{PhI}(\mathrm{OAc})_{2}(1.3 \mathrm{~g}, 4.0 \mathrm{mmol})$ at room temperature. The reaction mixture was stirred at room temperature for 18 hours. After cooling to $0{ }^{\circ} \mathrm{C}$, the mixture was quenched with saturated $\mathrm{Na}_{2} \mathrm{~S}_{2} \mathrm{O}_{3}$ and extracted with DCM. The combined extract was washed with water and brine, dried over $\mathrm{Na}_{2} \mathrm{SO}_{4}$ and concentrated in vacuo. At last, the residue was purified by column chromatography (10:1 PE/EtOAc) to give $7(762 \mathrm{mg}, 83 \%)$ as colorless oil.

${ }^{1} \mathbf{H}$ NMR $\left(400 \mathrm{MHz}, \mathrm{CDCl}_{3}\right) \delta 7.43-7.27(\mathrm{~m}, 5 \mathrm{H}), 4.54(\mathrm{~s}, 2 \mathrm{H}), 4.22(\mathrm{~d}, J=4.6 \mathrm{~Hz}$, $1 \mathrm{H}), 3.82(\mathrm{dd}, J=9.7,2.4 \mathrm{~Hz}, 1 \mathrm{H}), 3.72-3.56(\mathrm{~m}, 3 \mathrm{H}), 2.35-2.14(\mathrm{~m}, 4 \mathrm{H}), 1.91$ $(\mathrm{dd}, J=10.6,5.5 \mathrm{~Hz}, 1 \mathrm{H}), 1.84-1.66(\mathrm{~m}, 5 \mathrm{H}), 1.56-1.47(\mathrm{~m}, 2 \mathrm{H}), 1.34-1.20(\mathrm{~m}$, $2 \mathrm{H}), 0.85(\mathrm{~s}, 9 \mathrm{H}), 0.02(\mathrm{~d}, J=1.5 \mathrm{~Hz}, 6 \mathrm{H})$.

${ }^{13}$ C NMR $\left(100 \mathrm{MHz}, \mathrm{CDCl}_{3}\right) \delta 209.5,137.0,128.7,128.2,128.0,78.7,73.8,69.6$, 66.7, 41.8, 41.7, 40.0, 36.3, 33.7, 33.0, 32.8, 25.7, 25.4, 23.6, 18.0, 16.8, -4.6, -4.9.

HRMS (ES+) exact mass calculated for $[\mathrm{M}+\mathrm{H}]^{+}\left(\mathrm{C}_{27} \mathrm{H}_{43} \mathrm{O}_{4} \mathrm{Si}{ }^{+}\right)$requires $\mathrm{m} / \mathrm{z}$ : 459.2925, found $\mathrm{m} / \mathrm{z}: 459.2921$. 


\section{Preparation of Compound 8}

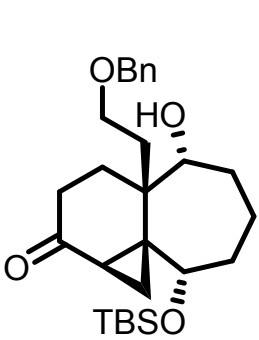

7
1. TBAF, THF $50^{\circ} \mathrm{C}, \mathrm{mw}, 1 \mathrm{~h}$

2. $\mathrm{Ac}_{2} \mathrm{O}$,pyridine

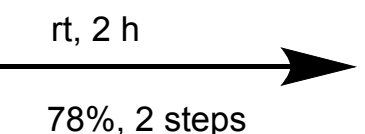

$78 \%, 2$ steps

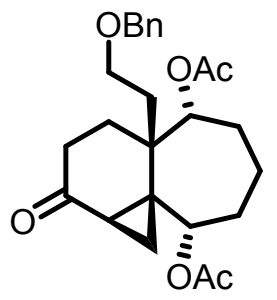

8

7 (229 mg, $0.5 \mathrm{mmol})$, TBAF (5 mL, 1.0 M in THF solution, $5.0 \mathrm{mmol}$ ) and THF (5 $\mathrm{mL}$ ) were loaded into the microwave instrument vial. The vial was sealed and irradiated with stirring at a ceiling temperature of $50{ }^{\circ} \mathrm{C}$ at low absorption power level for 1 hour. Upon completion of the reaction time the vial was cooled with a stream of air. The reaction mixture was then quenched with saturated $\mathrm{NH}_{4} \mathrm{Cl}$ solution and extracted with EtOAc. The combined extract was washed with water and brine, dried over $\mathrm{Na}_{2} \mathrm{SO}_{4}$ and concentrated in vacuo. The crude diol was used in the next step without further purification.

To a stirred solution of diol (assuming $0.5 \mathrm{mmol}$ ) in dry tetrahydrofuran $(5 \mathrm{~mL})$ was added dry pyridine $(791 \mathrm{mg}, 10.0 \mathrm{mmol})$ and acetic anhydride $(1.0 \mathrm{~g}, 10.0 \mathrm{mmol})$ consecutively at room temperature. The reaction mixture was stirred at room temperature for 2 hours. The reaction mixture was then quenched with saturated $\mathrm{NH}_{4} \mathrm{Cl}$ solution and extracted with EtOAc. The combined extract was washed with water and brine, dried over $\mathrm{Na}_{2} \mathrm{SO}_{4}$ and concentrated in vacuo. At last, the residue was purified by column chromatography $(2: 1 \mathrm{PE} / \mathrm{EtOAc})$ to give 8 (167 mg, 78\% over 2 steps) as a white crystal.

${ }^{1} \mathbf{H}$ NMR $\left(400 \mathrm{MHz}, \mathrm{CDCl}_{3}\right) \delta 7.36-7.26(\mathrm{~m}, 5 \mathrm{H}), 5.27-5.14(\mathrm{~m}, 1 \mathrm{H}), 5.08-4.96$ $(\mathrm{m}, 1 \mathrm{H}), 4.55-4.39(\mathrm{~m}, 2 \mathrm{H}), 3.63-3.54(\mathrm{~m}, 2 \mathrm{H}), 2.31-2.07(\mathrm{~m}, 3 \mathrm{H}), 2.01-2.00$ (m, 3H), $1.97-1.96(\mathrm{~m}, 4 \mathrm{H}), 1.92-1.75(\mathrm{~m}, 6 \mathrm{H}), 1.75-1.61(\mathrm{~m}, 3 \mathrm{H}), 1.39-1.36$ $(\mathrm{m}, 1 \mathrm{H}), 1.23-1.19(\mathrm{~m}, 1 \mathrm{H})$.

${ }^{13}$ C NMR $\left(100 \mathrm{MHz}, \mathrm{CDCl}_{3}\right) \delta 208.6,170.2,169.4,138.2,128.5,127.8,127.8,80.5$, 73.4, 69.3, 66.1, 38.9, 38.3, 38.0, 33.6, 32.0, 30.9, 29.6, 27.9, 21.4, 21.1, 19.7, 15.3 .

HRMS (ES+) exact mass calculated for $[\mathrm{M}+\mathrm{Na}]^{+}\left(\mathrm{C}_{25} \mathrm{H}_{32} \mathrm{O}_{6} \mathrm{Na}^{+}\right)$requires $\mathrm{m} / \mathrm{z}$ : 451.2091, found m/z: 451.2090 . 


\section{Preparation of Compound S1}

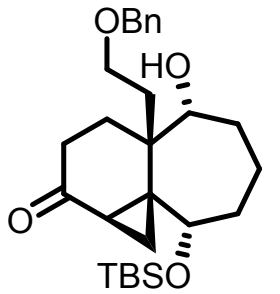

7

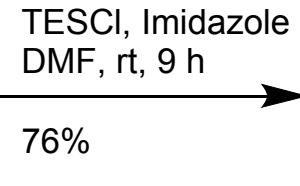

$76 \%$

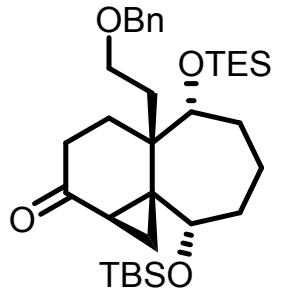

S1

To a solution of 7 (1.23 g, $2.68 \mathrm{mmol})$ and imidazole (0.33 g, $4.82 \mathrm{mmol})$ in DMF (11 $\mathrm{mL})$ was added triethylchlorosilane $(0.73 \mathrm{~g}, 4.82 \mathrm{mmol})$ in one portion. The mixture was stirred at room temperature for 9 hours. The reaction was quenched with saturated $\mathrm{NaHCO}_{3}$ solution and extracted with EtOAc. The combined extract was washed with water and brine, dried over $\mathrm{Na}_{2} \mathrm{SO}_{4}$ and concentrated in vacuo. At last, the residue was purified by column chromatography (10:1 PE/EtOAc) gave S1 (1.17 $\mathrm{g}, 76 \%)$ as colorless oil.

${ }^{1} \mathbf{H}$ NMR $\left(400 \mathrm{MHz}, \mathrm{CDCl}_{3}\right) \delta 7.42-7.21(\mathrm{~m}, 5 \mathrm{H}), 4.50(\mathrm{~s}, 2 \mathrm{H}), 3.90(\mathrm{~d}, J=9.5 \mathrm{~Hz}$, $1 \mathrm{H}), 3.74(\mathrm{~d}, J=8.2 \mathrm{~Hz}, 1 \mathrm{H}), 3.62(\mathrm{t}, J=7.6 \mathrm{~Hz}, 2 \mathrm{H}), 2.20(\mathrm{t}, J=6.9 \mathrm{~Hz}, 2 \mathrm{H}), 2.08-$ $1.90(\mathrm{~m}, 4 \mathrm{H}), 1.87-1.83(\mathrm{~m}, 1 \mathrm{H}), 1.76-1.63(\mathrm{~m}, 5 \mathrm{H}), 1.60-1.47(\mathrm{~m}, 2 \mathrm{H}), 1.40-$ $1.32(\mathrm{~m}, 1 \mathrm{H}), 0.92$ (t, $J=7.8 \mathrm{~Hz}, 9 \mathrm{H}), 0.83(\mathrm{~s}, 9 \mathrm{H}), 0.57$ (q, $J=7.9 \mathrm{~Hz}, 6 \mathrm{H}), 0.02$ (s, $6 \mathrm{H})$.

${ }^{13} \mathrm{C}$ NMR $\left(100 \mathrm{MHz}, \mathrm{CDCl}_{3}\right) \delta 210.4,138.3,128.5,127.8(2 \mathrm{C}), 80.1,73.4,68.1$, $67.1,40.5,39.7,36.6,33.9,33.2,31.0,28.4,25.8,22.1,18.1,16.5,7.1,5.3(2 \mathrm{C}),-4.4$, -4.7 .

HRMS (ES+) exact mass calculated for $[\mathrm{M}+\mathrm{H}]^{+}\left(\mathrm{C}_{33} \mathrm{H}_{57} \mathrm{O}_{4} \mathrm{Si}_{2}{ }^{+}\right)$requires $\mathrm{m} / \mathrm{z}$ : 573.3790, found $\mathrm{m} / \mathrm{z}: 573.3788$. 
Preparation of Compound S2

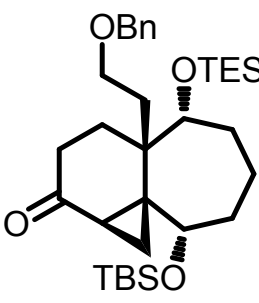

S1
1) TMSOTf, TEA $\mathrm{DCM}, \mathrm{rt}, 30 \mathrm{~min}$

2) $\mathrm{Pd}(\mathrm{OAc})_{2}, \mathrm{MeCN}$ $\mathrm{rt}, 3 \mathrm{~h}$ $92 \%, 2$ steps

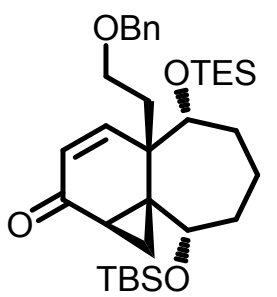

S2

Method A: To an argon-purged stirred solution of S1 (573 mg, $1.0 \mathrm{mmol}$ ) in DCM $(10 \mathrm{~mL})$ at room temperature was added TEA $(1.01 \mathrm{~g}, 10.0 \mathrm{mmol})$ and TMSOTf $(1.11$ $\mathrm{g}, 5.0 \mathrm{mmol}$ ). The reaction mixture was stirred at the same temperature for $30 \mathrm{~min}$. The mixture was quenched with saturated $\mathrm{NaHCO}_{3}$ solution and extracted with $\mathrm{Et}_{2} \mathrm{O}$. The combined extract was washed with brine, dried over $\mathrm{Na}_{2} \mathrm{SO}_{4}$ and concentrated in vacuo. The crude silyl enol ether was used in the next step without further purification.

The silyl enol ether (ca. $1.0 \mathrm{mmol}$ ) was dissolved in $10 \mathrm{~mL} \mathrm{MeCN}$ at room temperature. Then $\mathrm{Pd}(\mathrm{OAc})_{2}(247 \mathrm{mg}, 1.1 \mathrm{mmol})$ was added into the solution and the solution was stirred for 3 hours. The reaction was quenched with saturated $\mathrm{NaHCO}_{3}$ solution and extracted with EtOAc. The combined extract was washed with brine, dried over $\mathrm{Na}_{2} \mathrm{SO}_{4}$ and concentrated in vacuo. At last, the residue was purified by column chromatography (5:1 PE/EtOAc) to give $\mathbf{S 2}$ (492 mg, 86\%) as colorless oil.

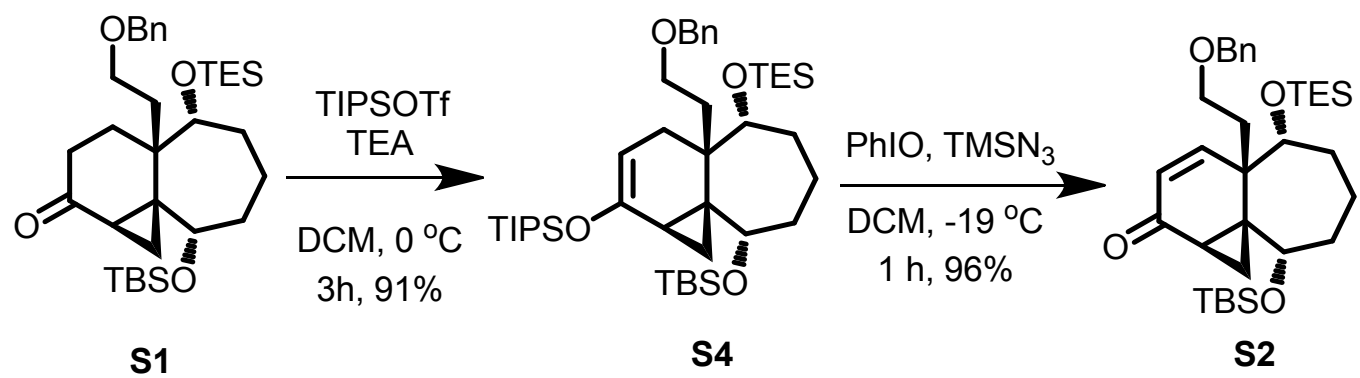

Method B: To an argon-purged stirred solution of S1 (400 mg, $0.7 \mathrm{mmol}$ ) in DCM (5 $\mathrm{mL})$ at $0{ }^{\circ} \mathrm{C}$ was added TEA (353 mg, $\left.3.5 \mathrm{mmol}\right)$ and TIPSOTf (428 g, $\left.1.4 \mathrm{mmol}\right)$. The reaction mixture was stirred at the same temperature for 3 hours. The mixture was quenched with saturated $\mathrm{NaHCO}_{3}$ solution and extracted with $\mathrm{Et}_{2} \mathrm{O}$. The combined extract was washed with brine, dried over $\mathrm{Na}_{2} \mathrm{SO}_{4}$ and concentrated in vacuo. At last, the residue was purified by column chromatography (50:1:0.1 $\mathrm{PE} / \mathrm{EtOAc} / \mathrm{TEA}$ ) to give $\mathbf{S 4}$ (464 mg, 91\%) as colorless oil.

To an argon-purged stirred solution of S4 $(140 \mathrm{mg}, 0.19 \mathrm{mmol})$ and iodosylbenzene $(51 \mathrm{mg}, 0.23 \mathrm{mmol})$ in DCM $(2 \mathrm{~mL})$ at $-19{ }^{\circ} \mathrm{C}$ was added azidotrimethylsilane $(54$ $\mathrm{mg}, 0.48 \mathrm{mmol})$. The reaction mixture was stirred at the same temperature for 1 hour. The mixture was concentrated in vacuo. At last, the residue was purified by column chromatography (5:1 PE/EtOAc) to give $\mathbf{S 2}(80 \mathrm{mg}, 96 \%)$ as colorless oil. 
${ }^{1} \mathbf{H}$ NMR $\left(400 \mathrm{MHz}, \mathrm{CDCl}_{3}\right) \delta 7.44-7.16(\mathrm{~m}, 5 \mathrm{H}), 6.42(\mathrm{~d}, J=10.7 \mathrm{~Hz}, 1 \mathrm{H}), 5.86$ $(\mathrm{d}, J=10.7 \mathrm{~Hz}, 1 \mathrm{H}), 4.50(\mathrm{~s}, 2 \mathrm{H}), 3.90(\mathrm{~d}, J=9.7 \mathrm{~Hz}, 1 \mathrm{H}), 3.82(\mathrm{~d}, J=8.8 \mathrm{~Hz}, 1 \mathrm{H})$, $3.76-3.58(\mathrm{~m}, 2 \mathrm{H}), 2.24(\mathrm{dt}, J=14.1,7.2 \mathrm{~Hz}, 1 \mathrm{H}), 1.97-1.76(\mathrm{~m}, 4 \mathrm{H}), 1.71(\mathrm{~d}, J=$ $9.9 \mathrm{~Hz}, 2 \mathrm{H}), 1.60-1.41(\mathrm{~m}, 4 \mathrm{H}), 0.92(\mathrm{t}, J=8.1 \mathrm{~Hz}, 9 \mathrm{H}), 0.83(\mathrm{~s}, 9 \mathrm{H}), 0.57$ (q, $J=$ $7.8 \mathrm{~Hz}, 6 \mathrm{H}), 0.02(\mathrm{~s}, 6 \mathrm{H})$.

${ }^{13} \mathrm{C}$ NMR $\left(100 \mathrm{MHz}, \mathrm{CDCl}_{3}\right) \delta 198.7,151.1,138.1,128.5,127.8,127.7,125.3,79.7$, $73.3,67.9,67.1,45.5,37.6,37.5,36.1,32.5,28.4,27.0,25.8,23.9,18.1,7.0,5.2,-4.4$, -4.6 .

HRMS (ES+) exact mass calculated for $[\mathrm{M}+\mathrm{H}]^{+}\left(\mathrm{C}_{33} \mathrm{H}_{55} \mathrm{O}_{4} \mathrm{Si}_{2}{ }^{+}\right)$requires $\mathrm{m} / \mathrm{z}$ : 571.3633 , found $\mathrm{m} / \mathrm{z}: 571.3631$. 


\section{Preparation of Compound 9}

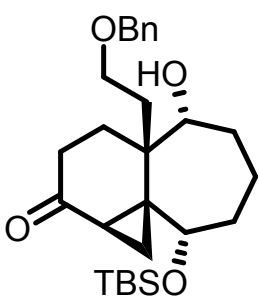

7
1) TMSOTf, TEA $\mathrm{DCM}, \mathrm{rt}, 30 \mathrm{~min}$

2) $\mathrm{Pd}(\mathrm{OAc})_{2}, \mathrm{MeCN}$ rt, $3 \mathrm{~h}$ then $2 \mathrm{M} \mathrm{HCl}$, THF $\mathrm{rt}, 15 \mathrm{~min}$ $86 \%, 2$ steps

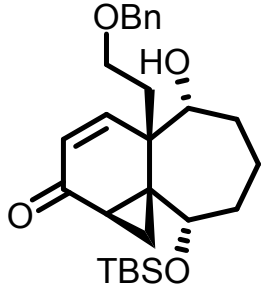

9

To an argon-purged stirred solution of $7(687 \mathrm{mg}, 1.5 \mathrm{mmol})$ in DCM $(15 \mathrm{~mL})$ at $0{ }^{\circ} \mathrm{C}$ was added TEA (1.52 g, $15.0 \mathrm{mmol})$ and TMSOTf $(1.63 \mathrm{~g}, 7.3 \mathrm{mmol})$. The reaction mixture was stirred at the same temperature for $30 \mathrm{~min}$. The mixture was quenched with saturated $\mathrm{NaHCO}_{3}$ solution and extracted with $\mathrm{Et}_{2} \mathrm{O}$. The combined extract was washed with brine, dried over $\mathrm{Na}_{2} \mathrm{SO}_{4}$ and concentrated in vacuo. The crude silyl enol ether was used in the next step without further purification.

The silyl enol ether (assuming $1.5 \mathrm{mmol}$ ) was dissolved in $15 \mathrm{~mL} \mathrm{MeCN}$ at room temperature. Then $\mathrm{Pd}(\mathrm{OAc})_{2}(371 \mathrm{mg}, 1.65 \mathrm{mmol})$ was added into the solution and the solution was stirred for 3 hours. The mixture was concentrated in vacuo. The residue was dissolved in $15 \mathrm{~mL}$ THF, then $1.5 \mathrm{~mL} 2 \mathrm{M} \mathrm{HCl}$ aqueous solution was added and stirred at room temperature for $15 \mathrm{~min}$. The reaction was quenched with saturated $\mathrm{NaHCO}_{3}$ solution and extracted with EtOAc. The combined extract was washed with brine, dried over $\mathrm{Na}_{2} \mathrm{SO}_{4}$ and concentrated in vacuo. At last, the residue was purified by column chromatography (5:1 PE/EtOAc) to give $9(590 \mathrm{mg}, 86 \%)$ as colorless oil.

${ }^{1} \mathbf{H}$ NMR $\left(400 \mathrm{MHz}, \mathrm{CDCl}_{3}\right) \delta 7.45-7.22(\mathrm{~m}, 5 \mathrm{H}), 6.55(\mathrm{~d}, J=10.8 \mathrm{~Hz}, 1 \mathrm{H}), 5.91$ $(\mathrm{d}, J=10.8 \mathrm{~Hz}, 1 \mathrm{H}), 4.54(\mathrm{~s}, 2 \mathrm{H}), 3.93(\mathrm{~d}, J=8.3 \mathrm{~Hz}, 2 \mathrm{H}), 3.85-3.65(\mathrm{~m}, 3 \mathrm{H}), 2.26$ $-2.05(\mathrm{~m}, 2 \mathrm{H}), 1.93-1.82(\mathrm{~m}, 1 \mathrm{H}), 1.82-1.62(\mathrm{~m}, 3 \mathrm{H}), 1.46(\mathrm{~d}, J=9.8 \mathrm{~Hz}, 4 \mathrm{H})$, $0.86-0.83(\mathrm{~m}, 9 \mathrm{H}), 0.01(\mathrm{~s}, 6 \mathrm{H})$.

${ }^{13}$ C NMR $\left(100 \mathrm{MHz}, \mathrm{CDCl}_{3}\right) \delta 198.2,148.5,137.0,128.3,127.8,127.6,125.9,79.1$, 73.3, 67.2, 66.6, 45.0, 39.1, 38.2, 37.0, 31.6, 29.4, 25.5, 23.8, 18.7, 17.7, -4.9, -5.0.

HRMS (ES+) exact mass calculated for $[\mathrm{M}+\mathrm{H}]^{+}\left(\mathrm{C}_{27} \mathrm{H}_{41} \mathrm{O}_{4} \mathrm{Si}^{+}\right)$requires $\mathrm{m} / \mathrm{z}$ : 457.2769, found $\mathrm{m} / \mathrm{z}: 457.2764$. 


\section{Preparation of Compound 12}

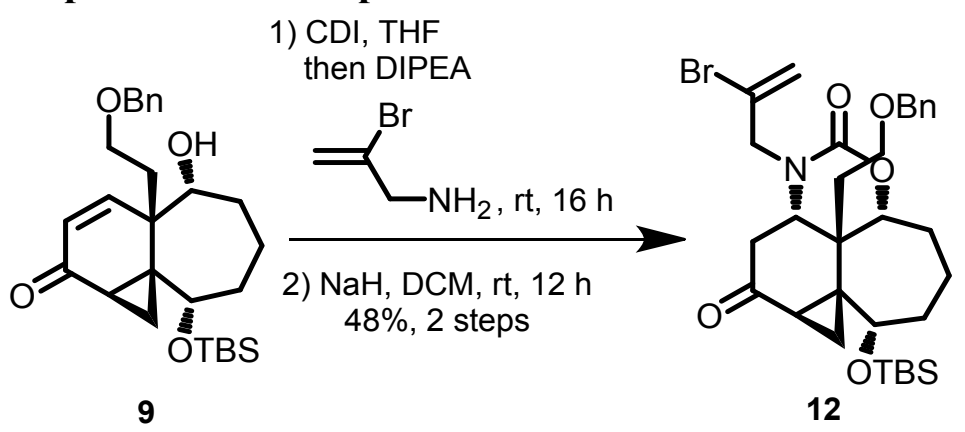

Under argon atmosphere CDI (136 mg, $0.84 \mathrm{mmol})$ was dissolved in THF $(1.2 \mathrm{~mL})$ and 9 (194 $\mathrm{mg}, 0.42 \mathrm{mmol})$ was added dropwise. After stirring at room temperature for 3 hours, DIPEA (546 mg, $4.2 \mathrm{mmol}$ ) and 2-bromoprop-2-en-1-amine (228 mg, $1.68 \mathrm{mmol}$ ) was added and the reaction was stirred for 16 hours. The reaction mixture was then quenched with saturated $\mathrm{NH}_{4} \mathrm{Cl}$ solution and extracted with EtOAc. The combined extract was washed with brine, dried over $\mathrm{Na}_{2} \mathrm{SO}_{4}$ and concentrated in vacuo. The crude carbamate was used in the next step without further purification.

To an argon-purged stirred solution of carbamate (assuming $0.42 \mathrm{mmol}$ ) in DCM (4 $\mathrm{mL})$ at room temperature was added $\mathrm{NaH}(60 \%$ dispersion in mineral oil, $68 \mathrm{mg}, 1.7$ mmol) portion-wise and stirred at the same temperature for 12 hours. The reaction mixture was then quenched with saturated $\mathrm{NH}_{4} \mathrm{Cl}$ solution and extracted with DCM, washed with brine, dried over $\mathrm{Na}_{2} \mathrm{SO}_{4}$ and concentrated in vacuo. At last, the residue was purified by column chromatography (3:1 PE/EtOAc) to give 12 (125 mg, 48\% over 2 steps) as pale-yellow oil.

${ }^{1} \mathbf{H}$ NMR $\left(400 \mathrm{MHz}, \mathrm{CDCl}_{3}\right) \delta 7.43-7.28(\mathrm{~m}, 5 \mathrm{H}), 5.33(\mathrm{~s}, 1 \mathrm{H}), 5.11(\mathrm{~s}, 1 \mathrm{H}), 4.60$ $(\mathrm{d}, J=15.1 \mathrm{~Hz}, 1 \mathrm{H}), 4.49$ (d, $J=10.8 \mathrm{~Hz}, 1 \mathrm{H}), 4.36(\mathrm{~d}, J=10.8 \mathrm{~Hz}, 1 \mathrm{H}), 4.03-3.77$ (m, 5H), $3.61(\mathrm{dd}, J=9.2,4.6 \mathrm{~Hz}, 1 \mathrm{H}), 2.63(\mathrm{dd}, J=19.5,6.9 \mathrm{~Hz}, 1 \mathrm{H}), 2.54-2.36$ $(\mathrm{m}, 2 \mathrm{H}), 2.06-2.01(\mathrm{~m}, 1 \mathrm{H}), 1.97(\mathrm{dd}, J=10.5,5.4 \mathrm{~Hz}, 1 \mathrm{H}), 1.86(\mathrm{~d}, J=13.8 \mathrm{~Hz}$, $1 \mathrm{H}), 1.83-1.59(\mathrm{~m}, 4 \mathrm{H}), 1.49-1.36(\mathrm{~m}, 1 \mathrm{H}), 1.34(\mathrm{~d}, J=5.1 \mathrm{~Hz}, 1 \mathrm{H}), 1.27-1.21$ (m, 1H), $0.85(\mathrm{~s}, 9 \mathrm{H}), 0.02(\mathrm{~d}, J=5.0 \mathrm{~Hz}, 6 \mathrm{H})$.

${ }^{13}$ C NMR $\left(100 \mathrm{MHz}, \mathrm{CDCl}_{3}\right) \delta 206.3,153.4,137.1,129.0(2 \mathrm{C}), 128.9,128.6,121.0$, $91.4,74.4,68.5,67.2,56.3,54.5,41.8,40.5,38.0,36.5,35.7,33.1,29.2,25.8,22.8$, 18.1, 14.1, -4.1, -4.6.

HRMS (ES+) exact mass calculated for $[\mathrm{M}+\mathrm{H}]^{+}\left(\mathrm{C}_{31} \mathrm{H}_{45} \mathrm{BrNO}_{5} \mathrm{Si}^{+}\right)$requires $\mathrm{m} / \mathrm{z}$ : 618.2245, found $\mathrm{m} / \mathrm{z}: 618.2237$. 


\section{Preparation of Compound 13}

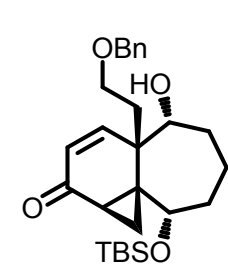

9

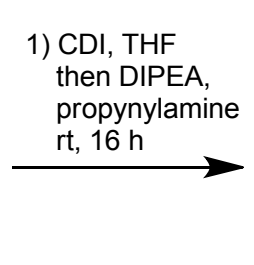

Under argon atmosphere CDI (61 mg, $0.38 \mathrm{mmol})$ was dissolved in THF $(1.1 \mathrm{~mL})$ and 9 (87 mg, $0.19 \mathrm{mmol})$ was added dropwise. After stirring at room temperature for 3 hours, DIPEA (245 mg, $1.9 \mathrm{mmol}$ ) and propargylamine (42 $\mathrm{mg}, 0.76 \mathrm{mmol}$ ) was added and the reaction was stirred for 16 hours. The reaction mixture was then quenched with saturated $\mathrm{NH}_{4} \mathrm{Cl}$ solution and extracted with EtOAc. The combined extract was washed with brine, dried over $\mathrm{Na}_{2} \mathrm{SO}_{4}$ and concentrated in vacuo. The crude carbamate $\mathbf{1 0}$ was used in the next step without further purification.

To an argon-purged stirred solution of carbamate $\mathbf{1 0}$ (assuming $0.19 \mathrm{mmol}$ ) in DCM $(1.3 \mathrm{~mL})$ at $0{ }^{\circ} \mathrm{C}$ was added trichloroisocyanuric acid $(47 \mathrm{mg}, 0.2 \mathrm{mmol})$. Then the mixture was raised to room temperature and stirred for 4 hours. The reaction mixture was then filtered and concentrated in vacuo. At last, the residue was purified by column chromatography (5:1 PE/EtOAc) to give 13 (57 mg, 52\% over 2 steps) as pale-yellow oil.

${ }^{1} \mathbf{H}$ NMR $\left(400 \mathrm{MHz}, \mathrm{CDCl}_{3}\right) \delta 7.45-7.22(\mathrm{~m}, 5 \mathrm{H}), 6.44(\mathrm{~d}, J=10.7 \mathrm{~Hz}, 1 \mathrm{H}), 5.95$ $(\mathrm{d}, J=10.7 \mathrm{~Hz}, 1 \mathrm{H}), 4.88(\mathrm{~d}, J=7.0 \mathrm{~Hz}, 1 \mathrm{H}), 4.49(\mathrm{~s}, 2 \mathrm{H}), 4.30(\mathrm{~d}, J=2.4 \mathrm{~Hz}, 2 \mathrm{H})$, $3.98(\mathrm{dd}, J=10.3,2.4 \mathrm{~Hz}, 1 \mathrm{H}), 3.78-3.55(\mathrm{~m}, 2 \mathrm{H}), 2.36(\mathrm{t}, J=2.4 \mathrm{~Hz}, 1 \mathrm{H}), 2.19-$ $2.12(\mathrm{~m}, 1 \mathrm{H}), 2.02-1.95(\mathrm{~m}, 1 \mathrm{H}), 1.93-1.88(\mathrm{~m}, 1 \mathrm{H}), 1.81(\mathrm{dd}, J=9.9,3.9 \mathrm{~Hz}, 1 \mathrm{H})$, $1.78-1.69(\mathrm{~m}, 2 \mathrm{H}), 1.66-1.46(\mathrm{~m}, 4 \mathrm{H}), 0.93(\mathrm{t}, J=4.6 \mathrm{~Hz}, 1 \mathrm{H}), 0.83(\mathrm{~s}, 9 \mathrm{H}), 0.01$ $(\mathrm{d}, J=2.9 \mathrm{~Hz}, 6 \mathrm{H})$.

${ }^{13} \mathrm{C}$ NMR $\left(100 \mathrm{MHz}, \mathrm{CDCl}_{3}\right) \delta 198.0,155.0,147.7,138.0,128.5,127.8,127.7$, $126.6,84.7,76.9,74.2,73.2,67.6,66.4,44.4,43.8,37.8,37.2,36.4,29.5,28.6,25.8$, $23.2,18.0,18.0,-4.5,-4.7$.

HRMS (ES+) exact mass calculated for $[\mathrm{M}+\mathrm{H}]^{+}\left(\mathrm{C}_{31} \mathrm{H}_{43} \mathrm{ClNO}_{5} \mathrm{Si}^{+}\right)$requires $\mathrm{m} / \mathrm{z}$ : 572.2594, found m/z: 572.2591 . 


\section{Preparation of Compound 2}

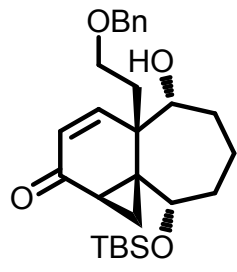

9

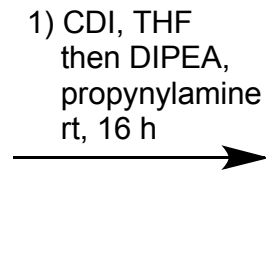

then DIPEA propynylamine $\mathrm{rt}, 16 \mathrm{~h}$

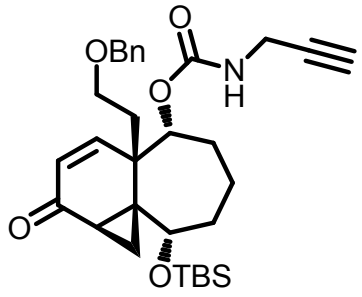

10
2) $\mathrm{NaH}, \mathrm{DCM}$

$\mathrm{rt}, 16 \mathrm{~h}$

$55 \%, 2$ steps

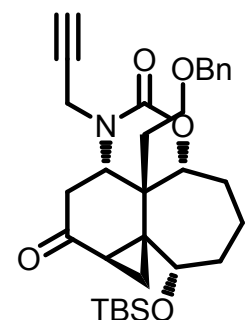

2

Under argon atmosphere CDI (323 mg, $2.0 \mathrm{mmol})$ was dissolved in THF (6 mL) and 9 (457 mg, $1.0 \mathrm{mmol}$ ) was added dropwise. After stirring at room temperature for 3 hours, DIPEA (1.27 g, $10.0 \mathrm{mmol})$ and propargylamine (221 $\mathrm{mg}, 4.0 \mathrm{mmol})$ was added and the reaction was stirred for 16 hours. The reaction mixture was then quenched with saturated $\mathrm{NH}_{4} \mathrm{Cl}$ solution and extracted with EtOAc. The combined extract was washed with brine, dried over $\mathrm{Na}_{2} \mathrm{SO}_{4}$ and concentrated in vacuo. The crude carbamate $\mathbf{1 0}$ was used in the next step without further purification.

To an argon-purged stirred solution of carbamate $\mathbf{1 0}$ (assuming $1.0 \mathrm{mmol}$ ) in DCM $(10 \mathrm{~mL})$ at room temperature was added $\mathrm{NaH}(60 \%$ dispersion in mineral oil, $160 \mathrm{mg}$, $4.0 \mathrm{mmol}$ ) portion-wise and stirred at the same temperature for 16 hours. The reaction mixture was then quenched with saturated $\mathrm{NH}_{4} \mathrm{Cl}$ solution and extracted with DCM, washed with brine, dried over $\mathrm{Na}_{2} \mathrm{SO}_{4}$ and concentrated in vacuo. At last, the residue was purified by column chromatography (3:1 PE/EtOAc) to give $2(296 \mathrm{mg}, 55 \%$ over 2 steps) as pale-yellow crystal.

${ }^{1} \mathbf{H}$ NMR $\left(400 \mathrm{MHz}, \mathrm{CDCl}_{3}\right) \delta 7.46-7.27$ (m, 5H), $4.56-4.38(\mathrm{~m}, 3 \mathrm{H}), 4.10-3.96$ $(\mathrm{m}, 3 \mathrm{H}), 3.91-3.86(\mathrm{~m}, 1 \mathrm{H}), 3.78(\mathrm{t}, J=9.6 \mathrm{~Hz}, 1 \mathrm{H}), 3.58-3.52(\mathrm{~m}, 1 \mathrm{H}), 2.82(\mathrm{ddd}$, $J=19.3,6.9,2.3 \mathrm{~Hz}, 1 \mathrm{H}), 2.43-2.27$ (m, 2H), $2.07-1.82(\mathrm{~m}, 4 \mathrm{H}), 1.79-1.65(\mathrm{~m}$, $3 \mathrm{H}), 1.47-1.25(\mathrm{~m}, 4 \mathrm{H}), 0.84(\mathrm{~s}, 9 \mathrm{H}),-0.00(\mathrm{~d}, J=9.1 \mathrm{~Hz}, 6 \mathrm{H})$.

${ }^{13} \mathrm{C}$ NMR $\left(100 \mathrm{MHz}, \mathrm{CDCl}_{3}\right) \delta$ 206.0, 152.6, 137.4, 128.8, 128.4, 128.4, 91.1, 78.5, 74.0, 73.2, 68.4, 66.4, 54.5, 41.2, 40.1, 38.3, 37.3, 36.6, 36.1, 33.1, 29.4, 25.8, 22.9, $18.1,14.3,-4.3,-4.7$.

HRMS (ES+) exact mass calculated for $[\mathrm{M}+\mathrm{H}]^{+}\left(\mathrm{C}_{31} \mathrm{H}_{44} \mathrm{NO}_{5} \mathrm{Si}^{+}\right)$requires $\mathrm{m} / \mathrm{z}$ : 538.2983, found m/z: 538.2978. 


\section{Preparation of Compound 15}

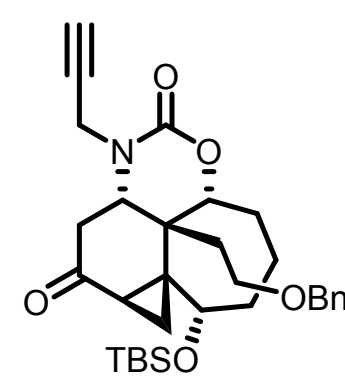

2

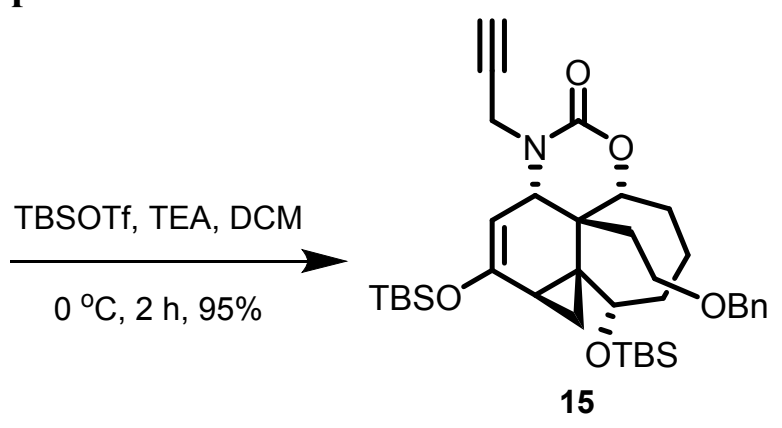

15

To an argon-purged stirred solution of $2(588 \mathrm{mg}, 1.1 \mathrm{mmol})$ in DCM $(11 \mathrm{~mL})$ at $0{ }^{\circ} \mathrm{C}$ was added TEA $(1.11 \mathrm{~g}, 11.0 \mathrm{mmol})$ and TBSOTf $(1.15 \mathrm{~g}, 4.4 \mathrm{mmol})$. The reaction mixture was stirred at the same temperature for 2 hours. The mixture was quenched with saturated $\mathrm{NaHCO}_{3}$ solution and extracted with $\mathrm{Et}_{2} \mathrm{O}$. The combined extract was washed with brine, dried over $\mathrm{Na}_{2} \mathrm{SO}_{4}$ and concentrated in vacuo. At last, the residue was purified by column chromatography (50:1:1 PE/EtOAc/TEA) to give $\mathbf{1 5}$ (681 mg, 95\%) as pale-yellow oil.

${ }^{1} \mathbf{H}$ NMR $\left(400 \mathrm{MHz}, \mathrm{CD}_{2} \mathrm{Cl}_{2}\right) \delta 7.37-7.28(\mathrm{~m}, 5 \mathrm{H}), 4.62(\mathrm{~s}, 1 \mathrm{H}), 4.55-4.29(\mathrm{~m}$, $2 \mathrm{H}), 4.20(\mathrm{~d}, J=17.5 \mathrm{~Hz}, 1 \mathrm{H}), 4.13-3.97(\mathrm{~m}, 3 \mathrm{H}), 3.92(\mathrm{~d}, J=11.1 \mathrm{~Hz}, 1 \mathrm{H}), 3.76-$ $3.60(\mathrm{~m}, 2 \mathrm{H}), 2.31(\mathrm{dt}, J=15.2,7.6 \mathrm{~Hz}, 1 \mathrm{H}), 2.21(\mathrm{~s}, 1 \mathrm{H}), 2.08-1.72(\mathrm{~m}, 5 \mathrm{H}), 1.55-$ $1.33(\mathrm{~m}, 4 \mathrm{H}), 1.14(\mathrm{t}, J=7.6 \mathrm{~Hz}, 1 \mathrm{H}), 0.96(\mathrm{~s}, 9 \mathrm{H}), 0.89(\mathrm{~s}, 9 \mathrm{H}), 0.19$ (d, $J=5.8 \mathrm{~Hz}$, $6 \mathrm{H}), 0.06(\mathrm{~s}, 6 \mathrm{H})$.

${ }^{13} \mathrm{C}$ NMR $\left(100 \mathrm{MHz}, \mathrm{CD}_{2} \mathrm{Cl}_{2}\right) \delta 153.5,152.8,138.6,128.8,128.3,128.1,98.2,90.6$, $79.4,73.7,72.5,68.5,67.1,56.7,38.8,38.2,37.9,37.1,33.4,32.6,26.0,25.9,22.9$, $19.7,18.4,18.3,15.1,-4.2,-4.2,-4.3,-4.7$.

HRMS (ES+) exact mass calculated for $[\mathrm{M}+\mathrm{H}]^{+}\left(\mathrm{C}_{37} \mathrm{H}_{58} \mathrm{NO}_{5} \mathrm{Si}_{2}{ }^{+}\right)$requires $\mathrm{m} / \mathrm{z}$ : 652.3848, found $\mathrm{m} / \mathrm{z}: 652.3838$. 


\section{Preparation of Compound 14}

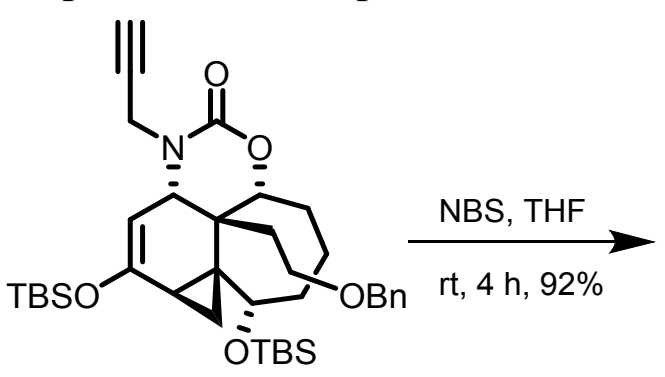

15

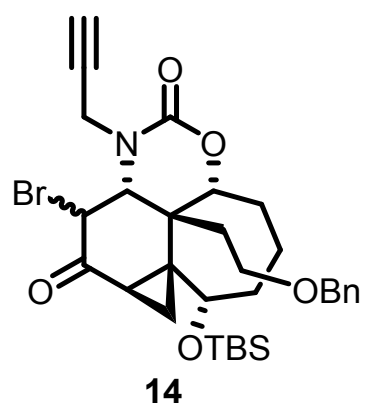

To an argon-purged stirred solution of $15(50 \mathrm{mg}, 0.072 \mathrm{mmol})$ in THF $(1.5 \mathrm{~mL})$ at room temperature was added NBS $(77 \mathrm{mg}, 0.432 \mathrm{mmol})$. The reaction mixture was stirred at the same temperature for 4 hours. The mixture was quenched with saturated $\mathrm{NaHCO}_{3}$ solution and extracted with EtOAc. The combined extract was washed with brine, dried over $\mathrm{Na}_{2} \mathrm{SO}_{4}$ and concentrated in vacuo. At last, the residue was purified by column chromatography $(2: 1 \mathrm{PE} /$ EtOAc) to give $\mathbf{1 4}(41 \mathrm{mg}, 92 \%, d r=6: 1)$ as a yellow oil.

${ }^{1} \mathbf{H}$ NMR of Major isomer: $\left(400 \mathrm{MHz}, \mathrm{CDCl}_{3}\right) \delta 7.37-7.30(\mathrm{~m}, 5 \mathrm{H}), 4.54(\mathrm{~s}, 1 \mathrm{H})$, $4.47-4.32(\mathrm{~m}, 2 \mathrm{H}), 4.17-4.09(\mathrm{~m}, 1 \mathrm{H}), 4.04-3.81(\mathrm{~m}, 3 \mathrm{H}), 3.79-3.60(\mathrm{~m}, 2 \mathrm{H})$, $2.58(\mathrm{dt}, J=14.8,7.4 \mathrm{~Hz}, 1 \mathrm{H}), 2.24-2.01(\mathrm{~m}, 3 \mathrm{H}), 1.94-1.80(\mathrm{~m}, 4 \mathrm{H}), 1.64-1.25$ (m, 5H), $0.85(\mathrm{~s}, 9 \mathrm{H}), 0.03(\mathrm{~d}, J=3.5 \mathrm{~Hz}, 6 \mathrm{H})$.

${ }^{13} \mathrm{C}$ NMR of Major isomer $\left(100 \mathrm{MHz}, \mathrm{CDCl}_{3}\right) \delta 200.6,153.0,137.5,128.8,128.3$, $128.3,89.9,78.0,74.0,73.8,68.8,66.5,65.6,48.6,45.9,39.8,39.0,38.0,36.6,32.7$, $28.9,25.8,21.6,18.1,16.2,-4.1,-4.7$.

HRMS (ES+) exact mass calculated for $[\mathrm{M}+\mathrm{H}]^{+}\left(\mathrm{C}_{31} \mathrm{H}_{43} \mathrm{BrNO}_{5} \mathrm{Si}^{+}\right)$requires $\mathrm{m} / \mathrm{z}$ : 616.2088, found m/z: 616.2079 . 


\section{Preparation of Compound 11}

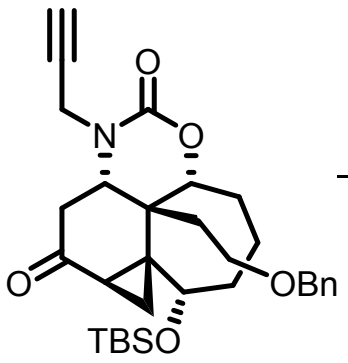

2

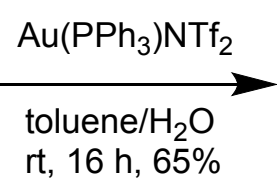

TBSO

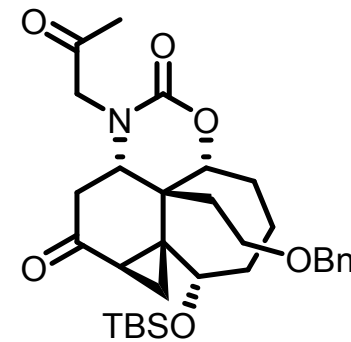

11

To an argon-purged stirred solution of $2(430 \mathrm{mg}, 0.8 \mathrm{mmol})$ in toluene $(8 \mathrm{~mL})$ and $\mathrm{H}_{2} \mathrm{O}(0.8 \mathrm{~mL})$ at room temperature was added $\mathrm{Au}\left(\mathrm{PPh}_{3}\right) \mathrm{NTf}_{2}(30 \mathrm{mg}, 0.04 \mathrm{mmol})$ and stirred at the same temperature for 16 hours. The reaction mixture was concentrated in vacuo. At last, the residue was purified by column chromatography (1:1 PE/EtOAc) to give $11(289 \mathrm{mg}, 65 \%)$ as colorless oil.

${ }^{1}$ H NMR $\left(400 \mathrm{MHz}, \mathrm{CDCl}_{3}\right) \delta 7.39-7.24(\mathrm{~m}, 5 \mathrm{H}), 4.49-4.30(\mathrm{~m}, 2 \mathrm{H}), 4.17(\mathrm{~d}, J=$ $18.2 \mathrm{~Hz}, 1 \mathrm{H}), 4.00(\mathrm{~d}, J=10.6 \mathrm{~Hz}, 1 \mathrm{H}), 3.94-3.81(\mathrm{~m}, 3 \mathrm{H}), 3.76(\mathrm{~d}, J=18.2 \mathrm{~Hz}$, $1 \mathrm{H}), 3.61-3.57(\mathrm{~m}, 1 \mathrm{H}), 2.72(\mathrm{dd}, J=19.7,6.9 \mathrm{~Hz}, 1 \mathrm{H}), 2.62(\mathrm{ddd}, J=15.3,11.1$, $3.9 \mathrm{~Hz}, 1 \mathrm{H}), 2.44$ (dd, $J=19.7,12.0 \mathrm{~Hz}, 1 \mathrm{H}), 2.06-2.00$ (m, 1H), 1.95 (dd, $J=10.6$, $5.4 \mathrm{~Hz}, 1 \mathrm{H}), 1.85(\mathrm{~s}, 4 \mathrm{H}), 1.81-1.65(\mathrm{~m}, 4 \mathrm{H}), 1.46-1.36(\mathrm{~m}, 1 \mathrm{H}), 1.27-1.21(\mathrm{~m}$, $2 \mathrm{H}), 0.84(\mathrm{~s}, 9 \mathrm{H}), 0.01(\mathrm{~d}, J=7.2 \mathrm{~Hz}, 6 \mathrm{H})$.

${ }^{13}$ C NMR (100 MHz, $\left.\mathrm{CDCl}_{3}\right) \delta 206.1,202.1,153.2,137.3,128.8,128.4,128.4,91.2$, 74.0, 68.3, 67.1, 58.6, 56.4, 41.6, 40.2, 37.8, 36.5, 35.6, 33.0, 29.0, 26.7, 25.7, 22.7, $18.0,14.0,-4.4,-4.8$.

HRMS (ES+) exact mass calculated for $[\mathrm{M}+\mathrm{H}]^{+}\left(\mathrm{C}_{31} \mathrm{H}_{46} \mathrm{NO}_{6} \mathrm{Si}^{+}\right)$requires $\mathrm{m} / \mathrm{z}$ : 556.3089 , found $\mathrm{m} / \mathrm{z}$ : 556.3085 . 


\section{Preparation of Compound 1}

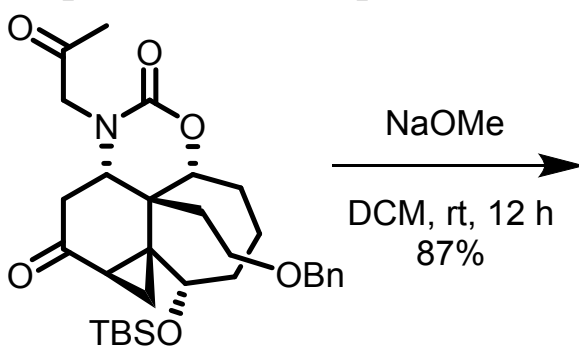

11

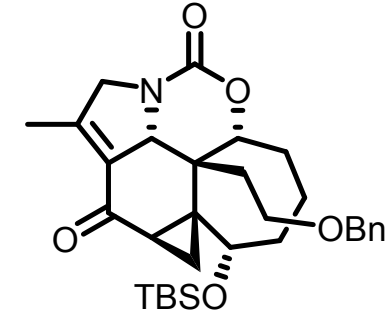

1

To an argon-purged stirred solution of 11 (278 $\mathrm{mg}, 0.5 \mathrm{mmol})$ in DCM (5 mL) at room temperature was added $\mathrm{NaOMe}(108 \mathrm{mg}, 2.0 \mathrm{mmol})$ and stirred at the same temperature for 12 hours. The reaction mixture was then quenched with saturated $\mathrm{NH}_{4} \mathrm{Cl}$ solution and extracted with DCM, washed with brine, dried over $\mathrm{Na}_{2} \mathrm{SO}_{4}$ and concentrated in vacuo. At last, the residue was purified by column chromatography (1:1 PE/EtOAc) to give $\mathbf{1}(233 \mathrm{mg}, 87 \%)$ as colorless oil.

${ }^{1} \mathbf{H}$ NMR $\left(400 \mathrm{MHz}, \mathrm{CDCl}_{3}\right) \delta 7.41-7.27(\mathrm{~m}, 5 \mathrm{H}), 4.55-4.41(\mathrm{~m}, 3 \mathrm{H}), 4.31$ (d, $J=$ $10.2 \mathrm{~Hz}, 1 \mathrm{H}), 4.19-4.13(\mathrm{~m}, 1 \mathrm{H}), 3.99(\mathrm{~d}, J=8.0 \mathrm{~Hz}, 1 \mathrm{H}), 3.92-3.69(\mathrm{~m}, 3 \mathrm{H}), 2.28$ (s, 3H), $2.18-2.10(\mathrm{~m}, 1 \mathrm{H}), 2.02(\mathrm{dd}, J=10.9,6.3 \mathrm{~Hz}, 1 \mathrm{H}), 1.88(\mathrm{dd}, J=11.0,5.0$ $\mathrm{Hz}, 1 \mathrm{H}), 1.82-1.75(\mathrm{~m}, 3 \mathrm{H}), 1.64-1.52(\mathrm{~m}, 2 \mathrm{H}), 1.47-1.42(\mathrm{~m}, 1 \mathrm{H}), 1.27-1.24$ $(\mathrm{m}, 1 \mathrm{H}), 1.04(\mathrm{t}, J=5.6 \mathrm{~Hz}, 1 \mathrm{H}), 0.85(\mathrm{~s}, 9 \mathrm{H}), 0.04(\mathrm{~d}, J=5.4 \mathrm{~Hz}, 6 \mathrm{H})$.

${ }^{13}$ C NMR $\left(100 \mathrm{MHz}, \mathrm{CDCl}_{3}\right) \delta 193.9,153.0,152.2,138.0,128.5,128.1,127.8(2 \mathrm{C})$, $85.1,73.3,67.3,66.9,65.8,57.3,42.9,40.3,37.6,37.5,32.5,30.9,25.7,24.8,18.0$, $16.7,14.4,-4.5,-4.7$.

HRMS (ES+) exact mass calculated for $[\mathrm{M}+\mathrm{H}]^{+}\left(\mathrm{C}_{31} \mathrm{H}_{44} \mathrm{NO}_{5} \mathrm{Si}^{+}\right)$requires $\mathrm{m} / \mathrm{z}$ : 538.2983, found m/z: 538.2981. 
5. ${ }^{1} \mathrm{H}$ and ${ }^{13} \mathrm{C}$ Spectra of compounds
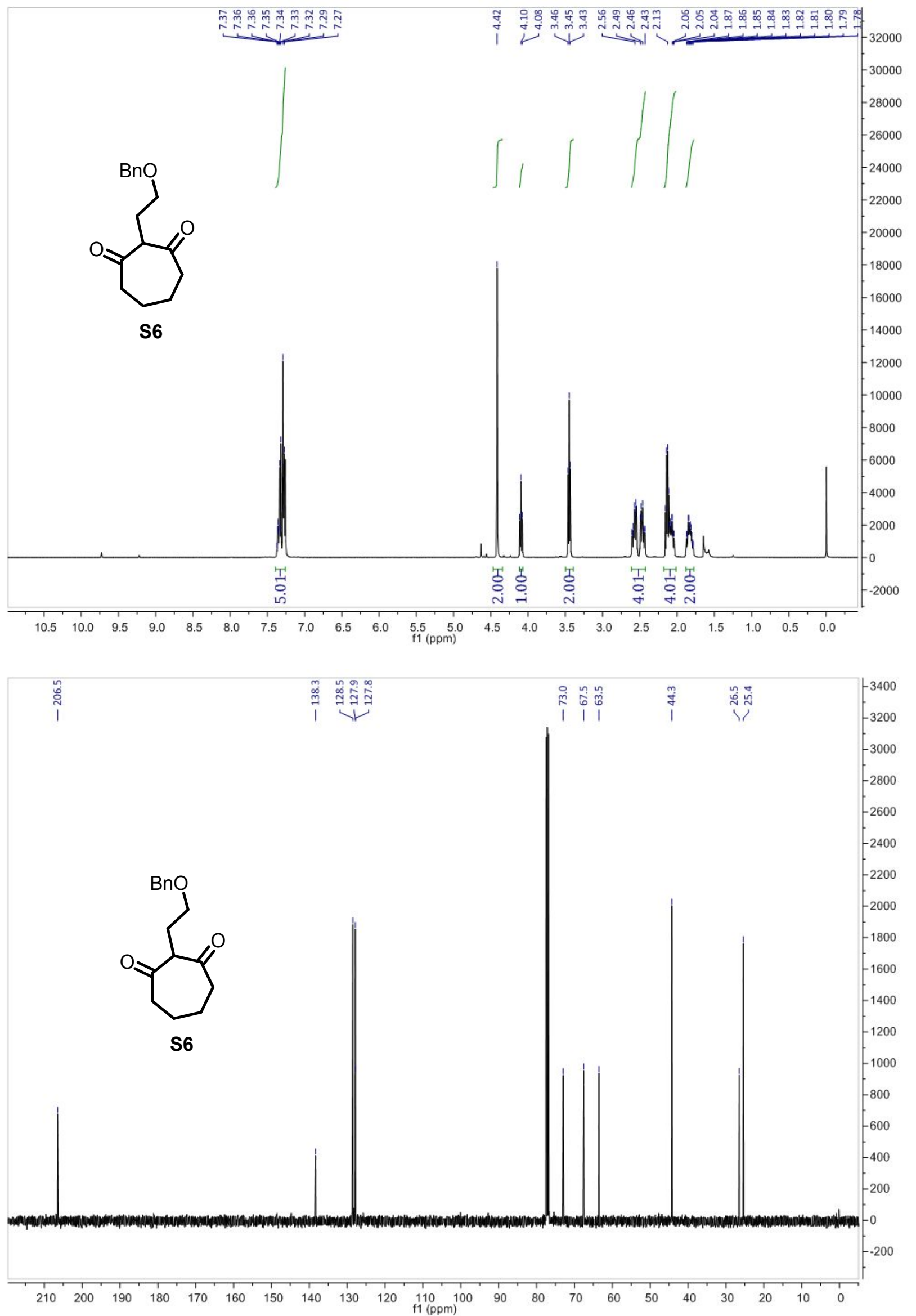

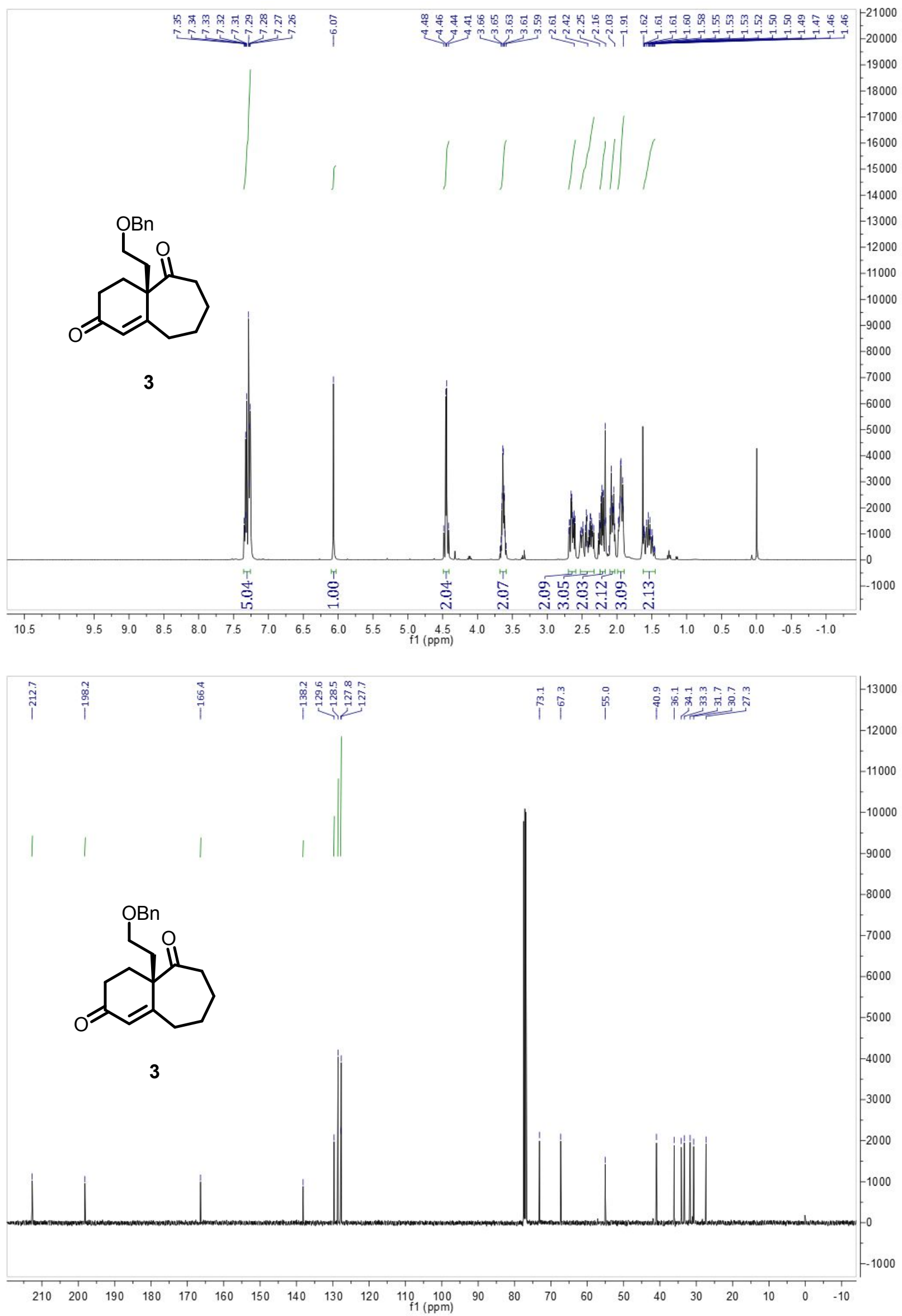

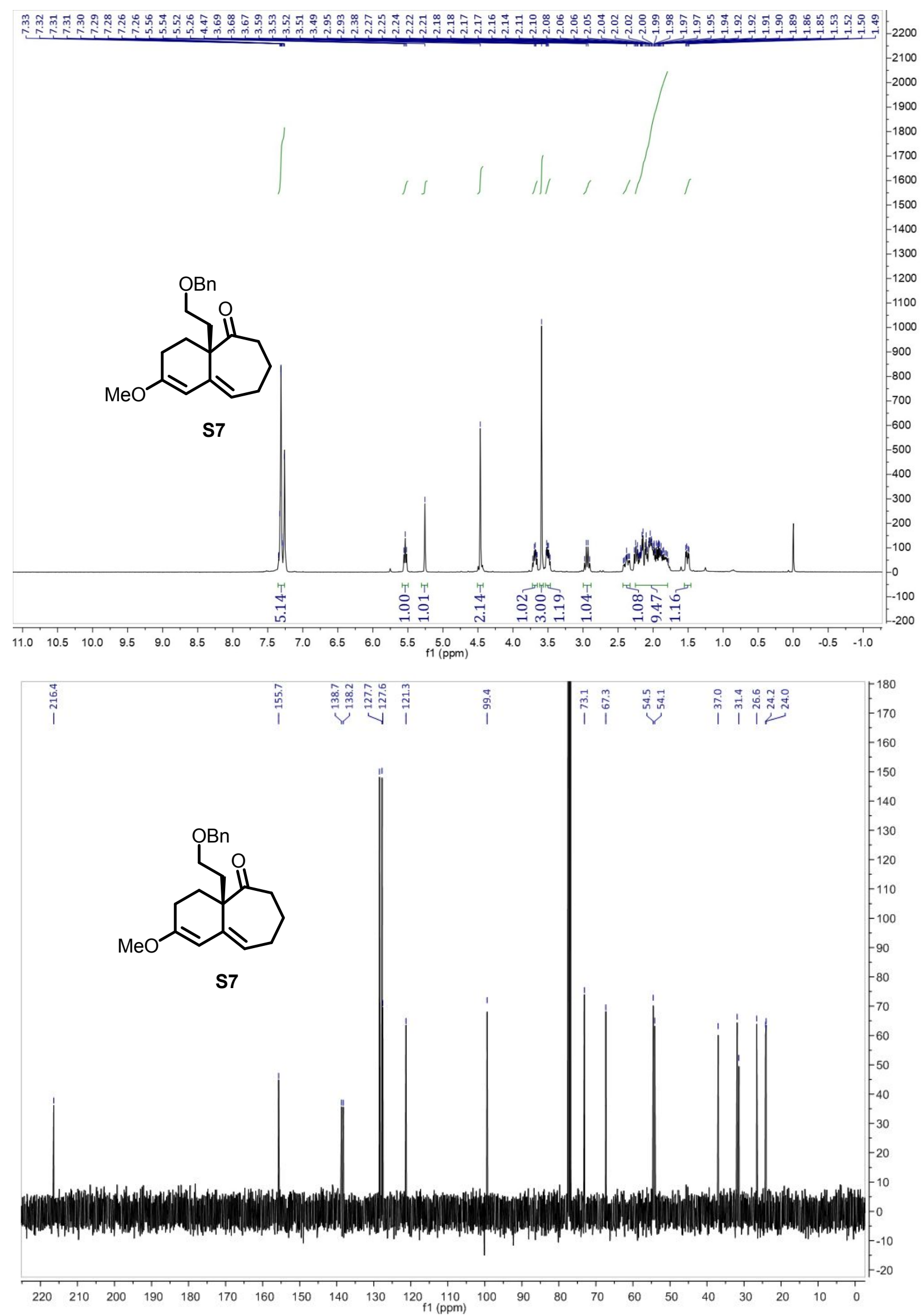


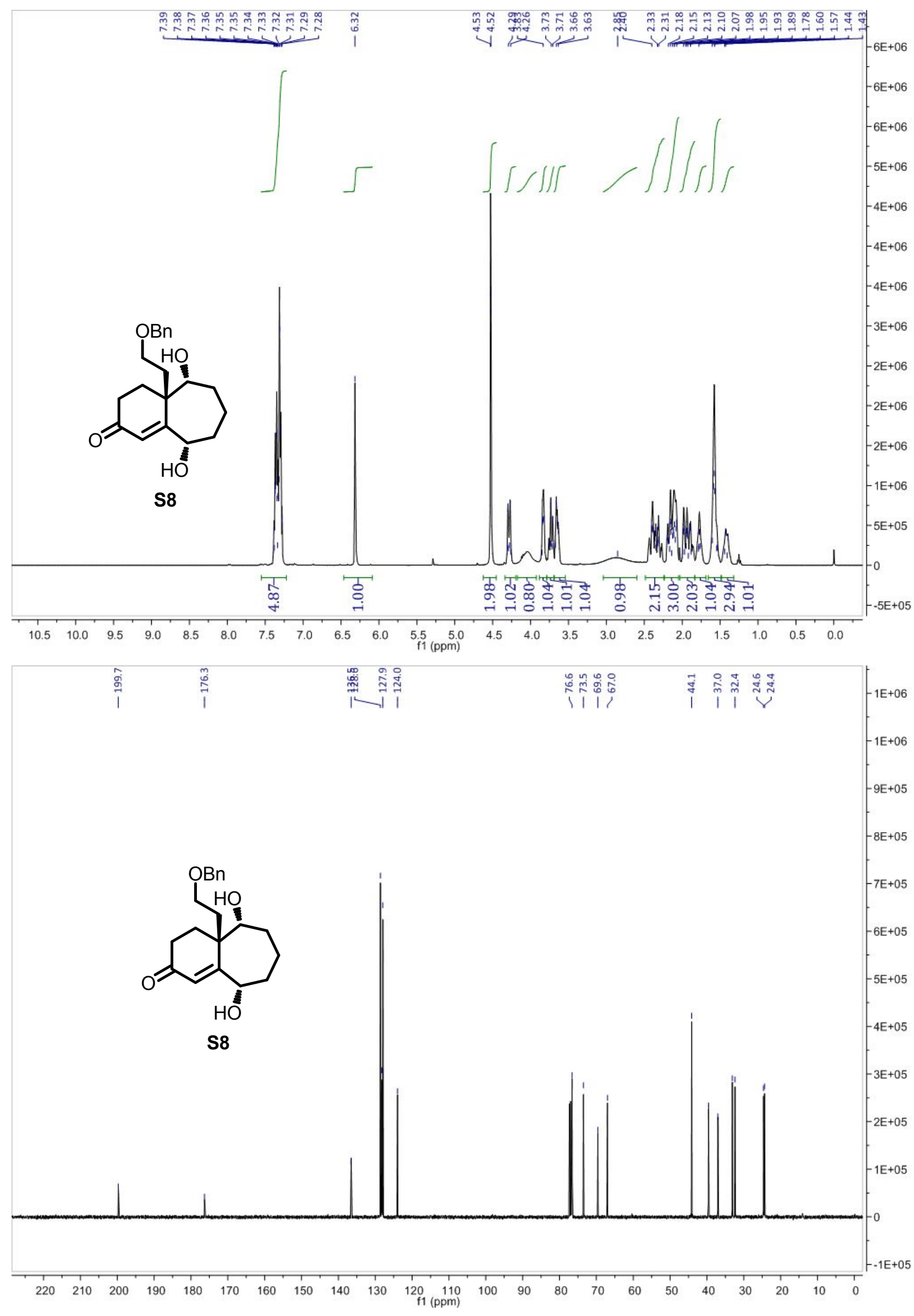



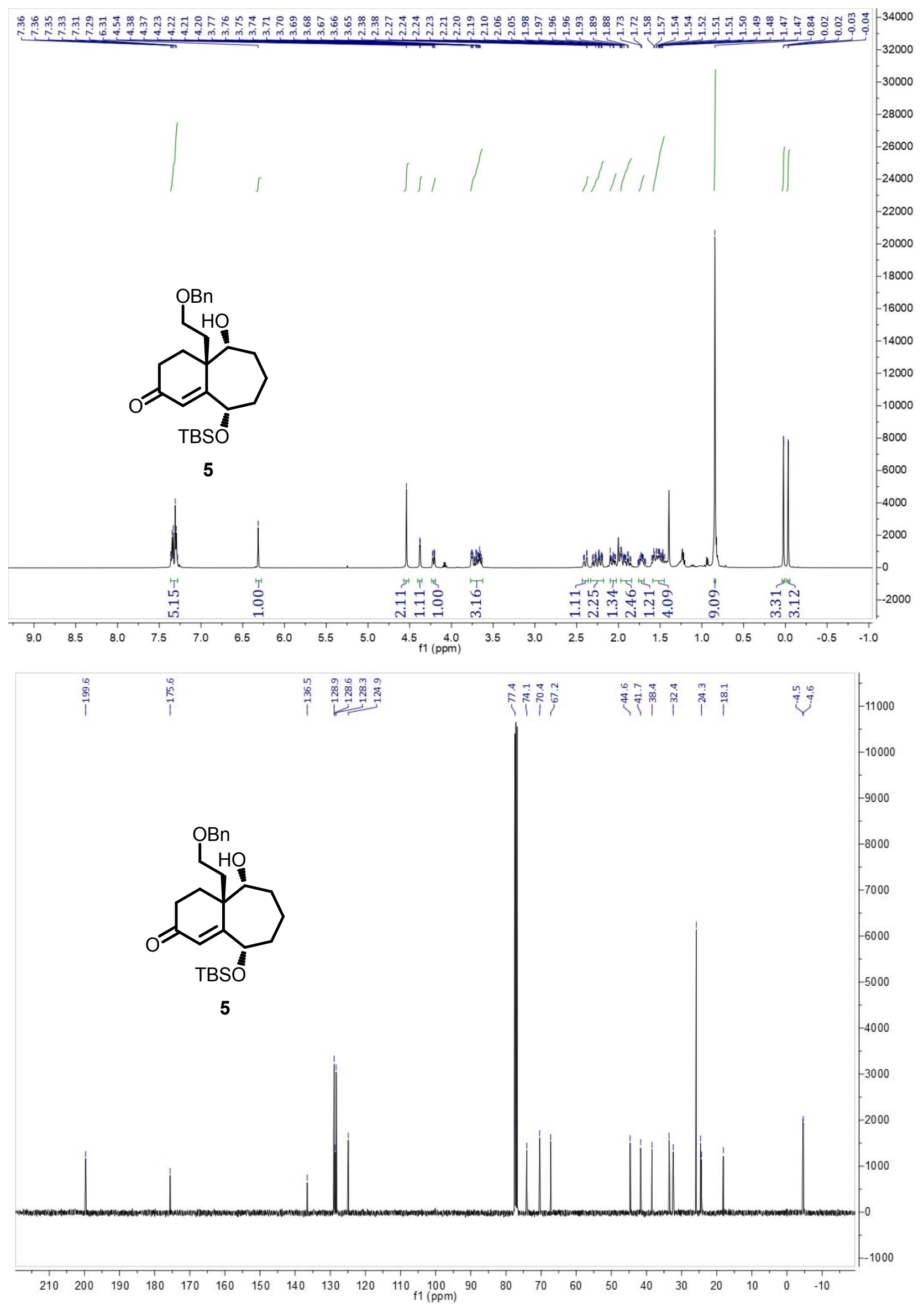


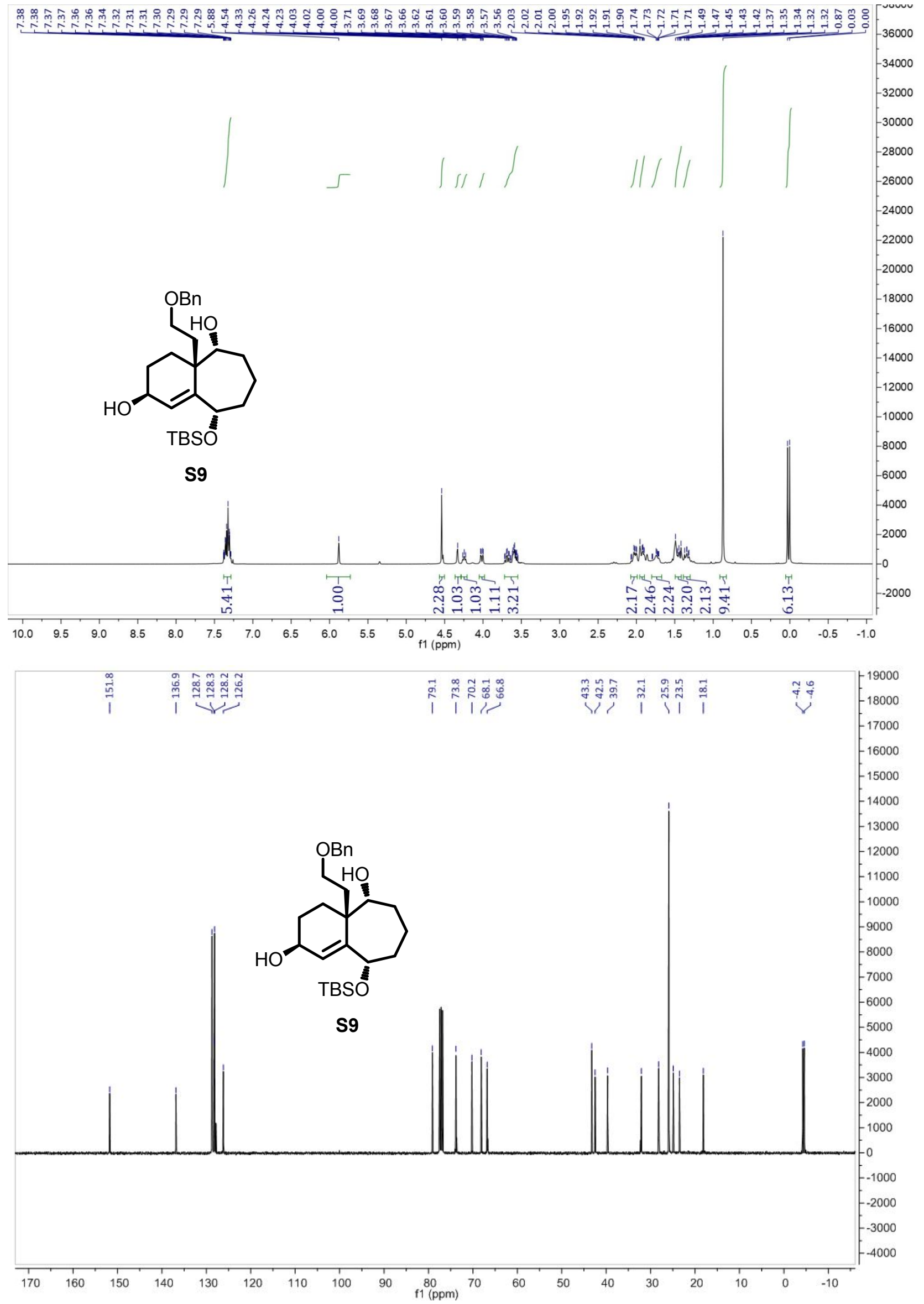



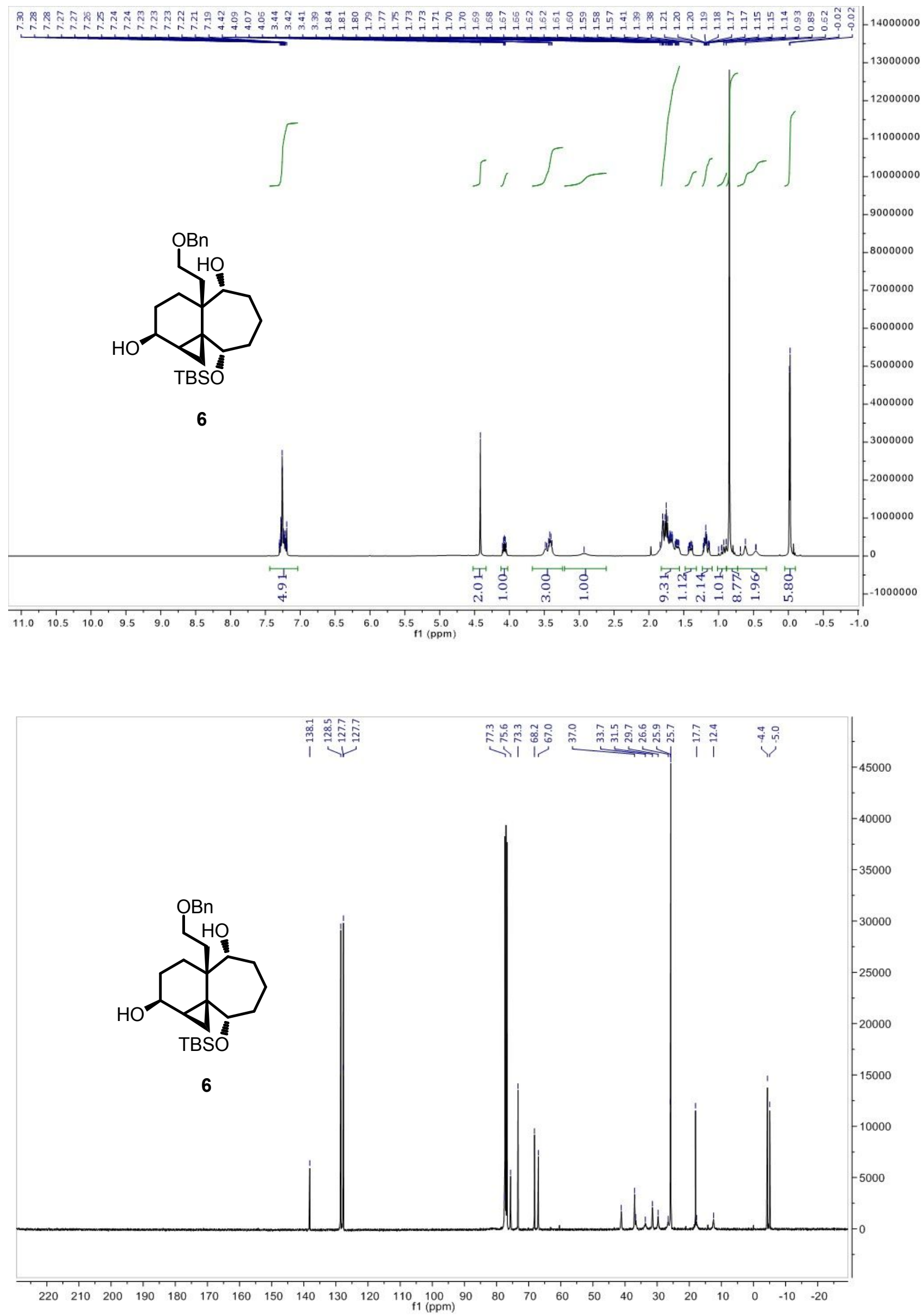

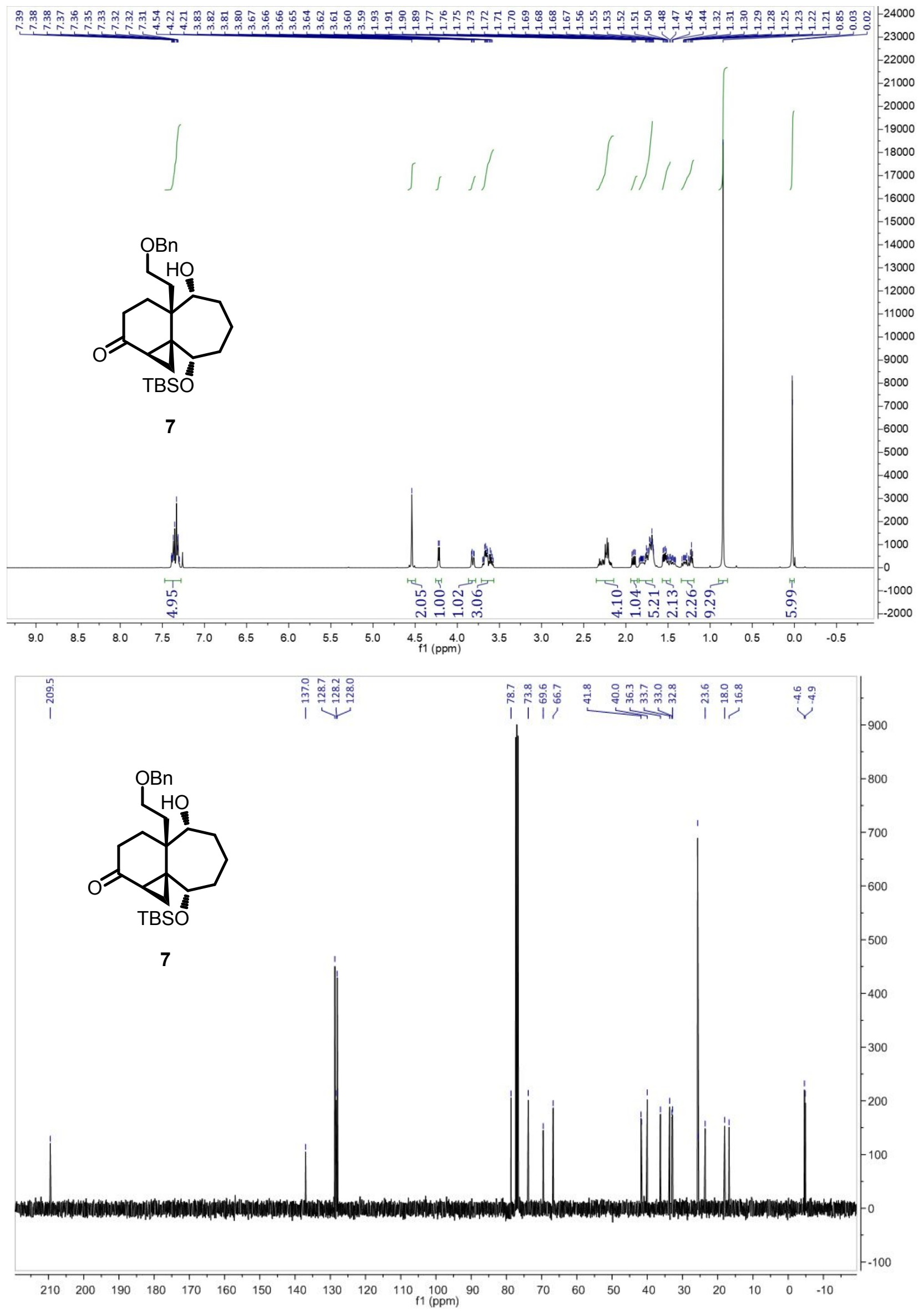

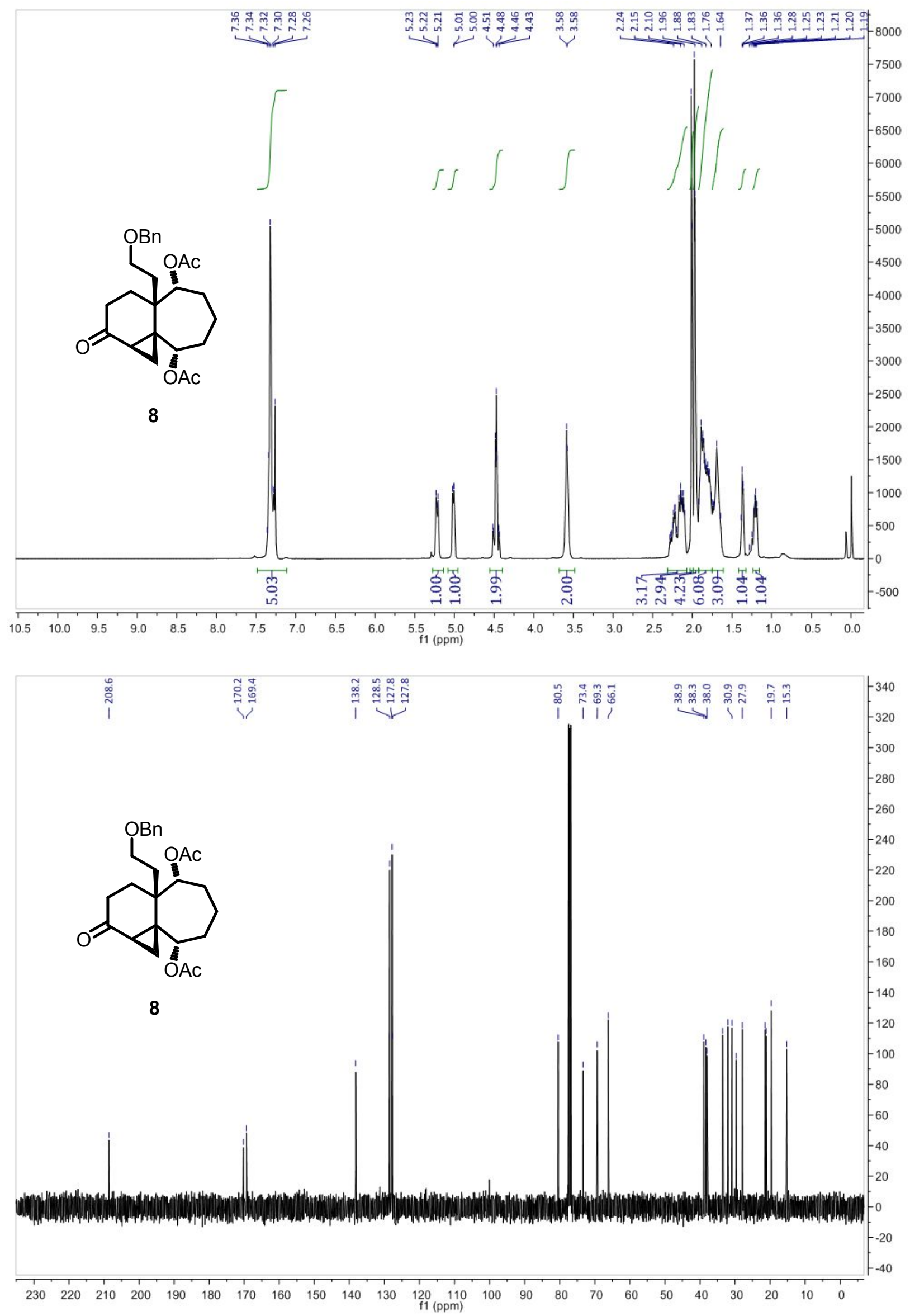

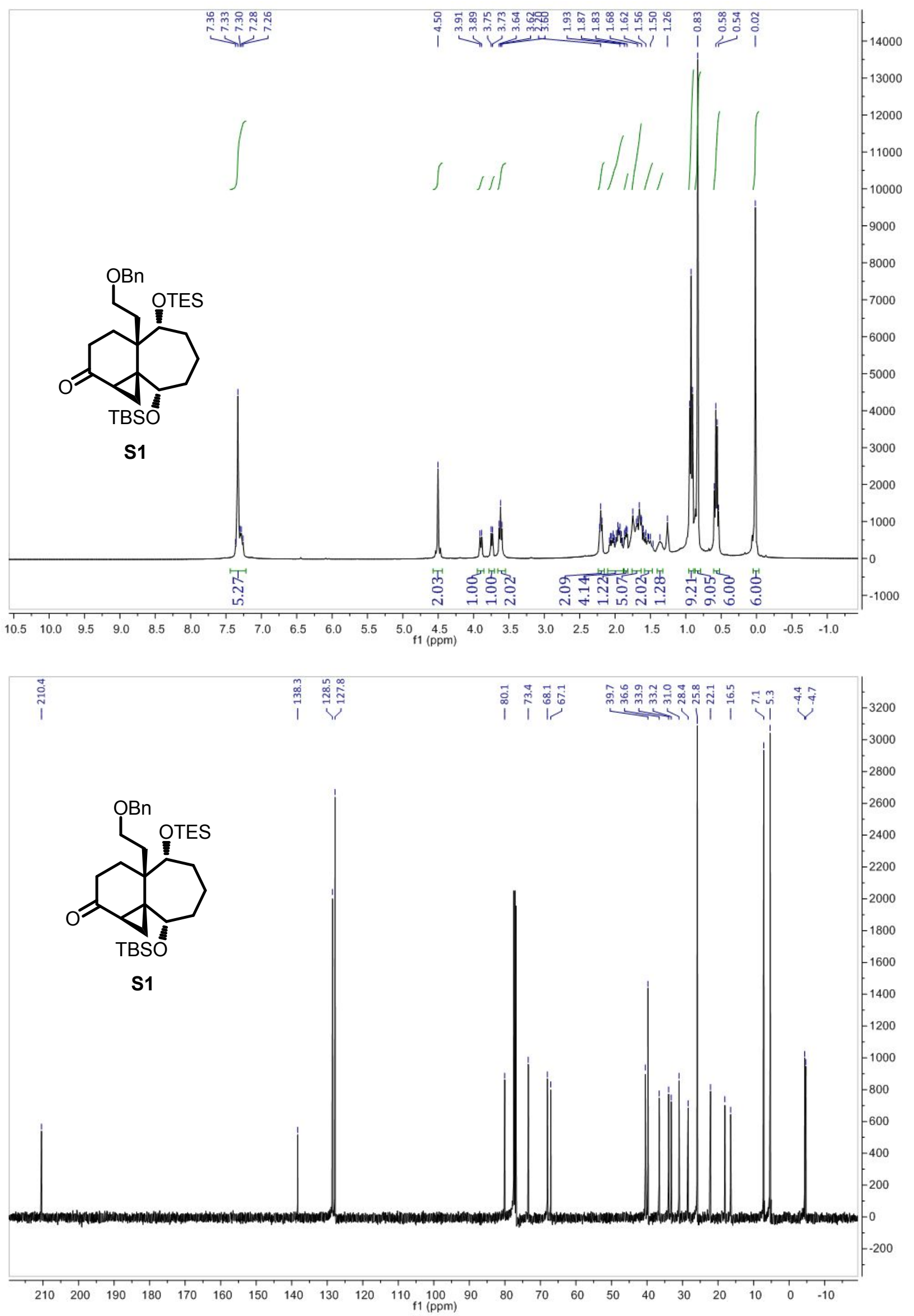

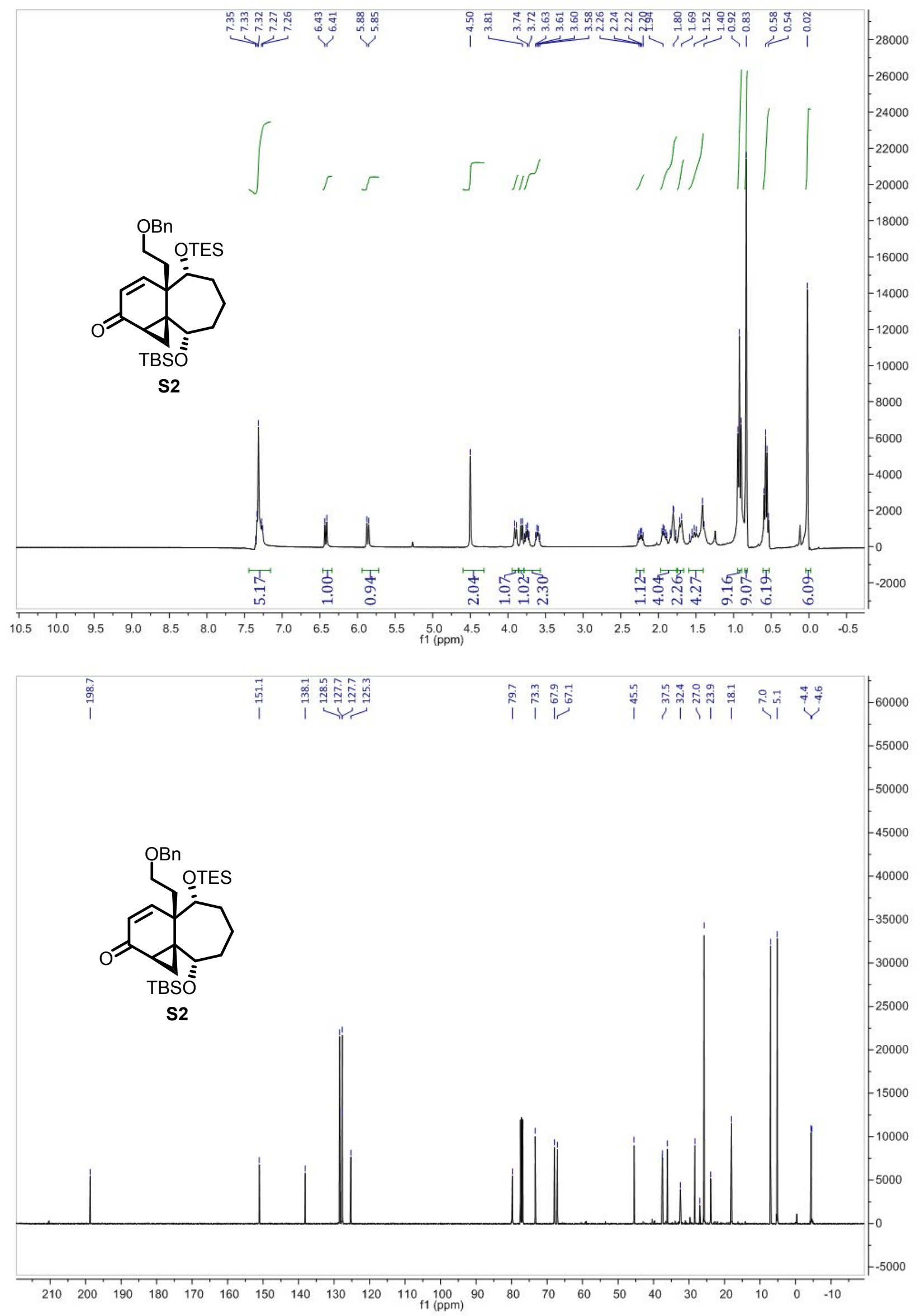

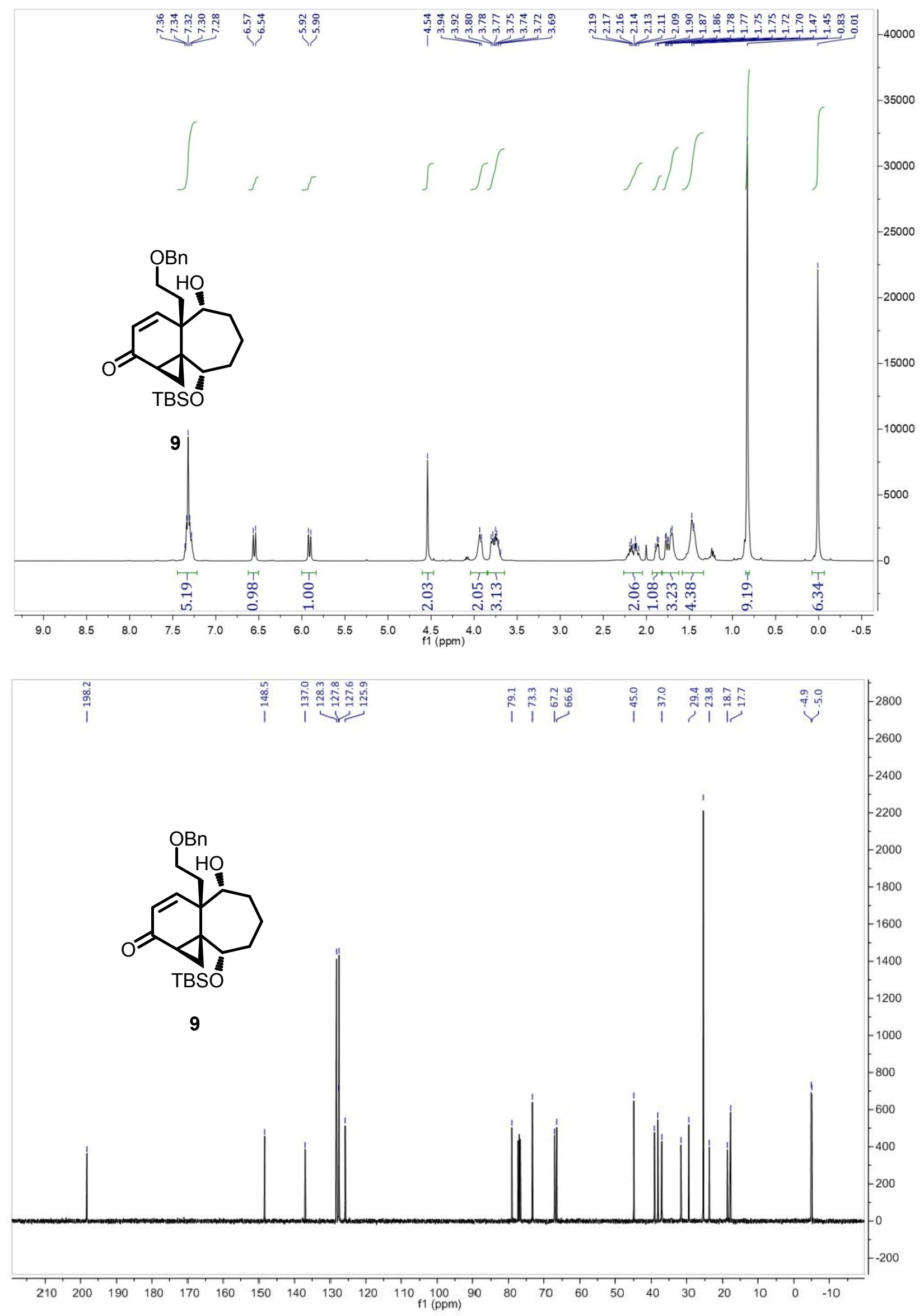


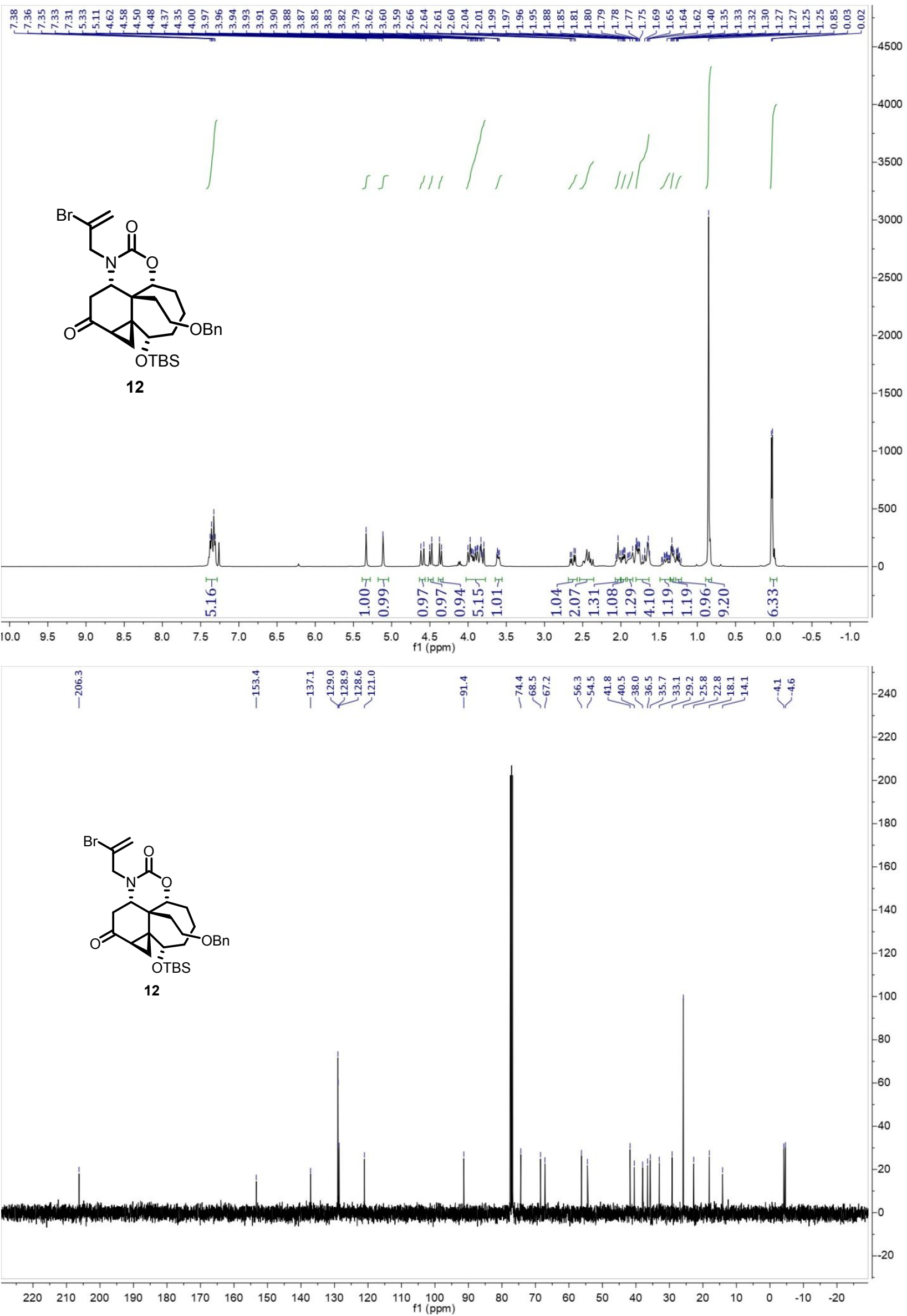




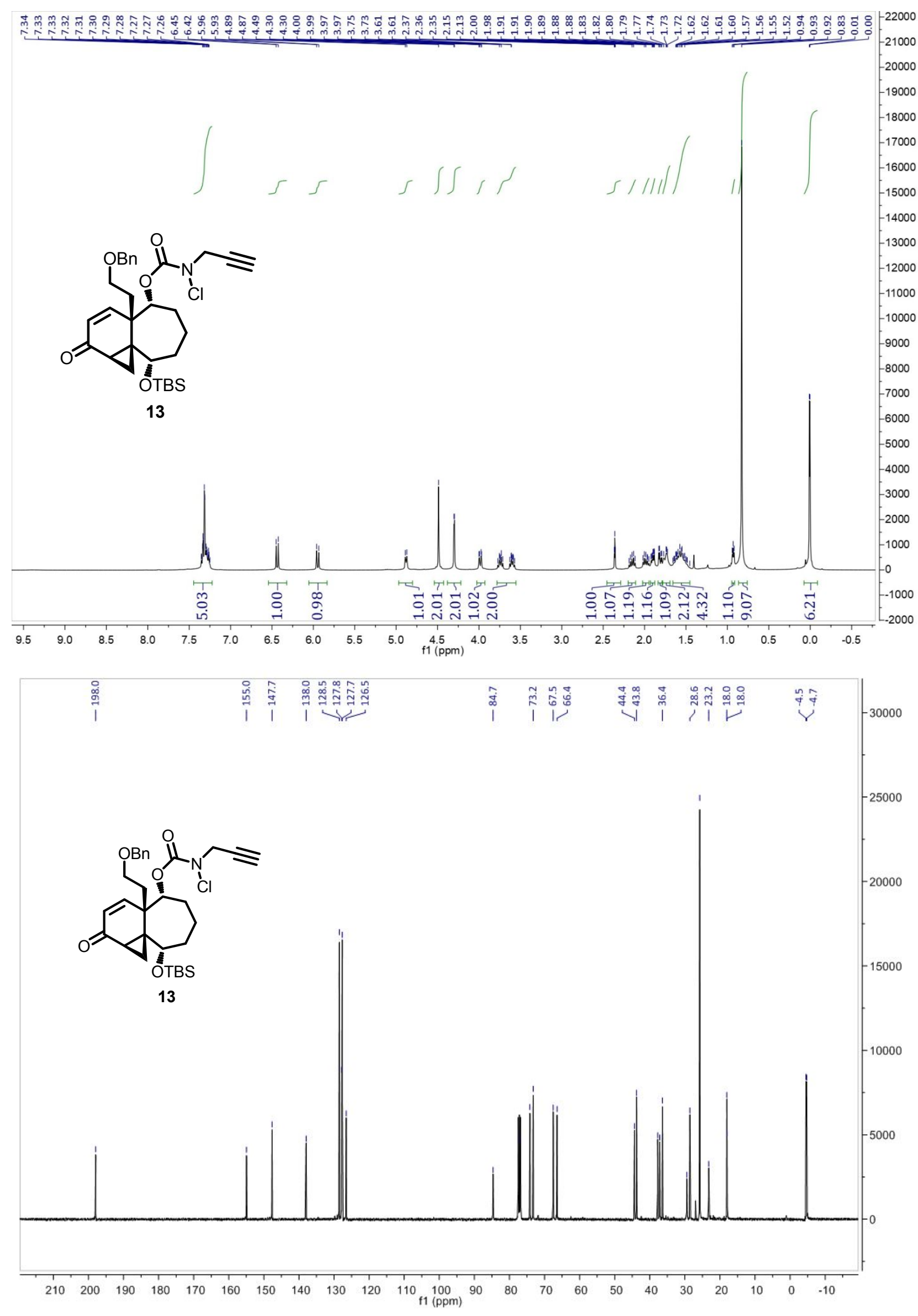




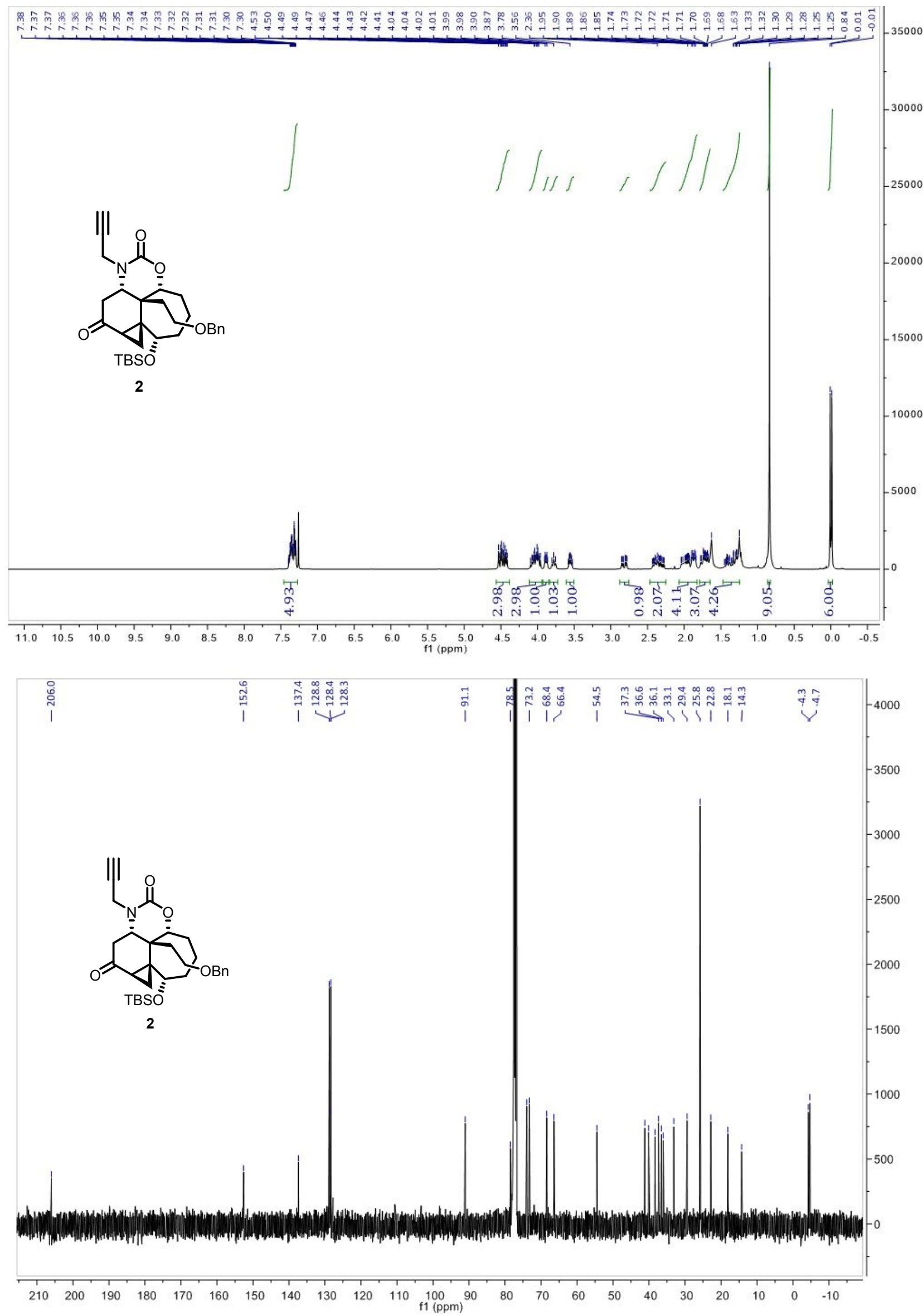




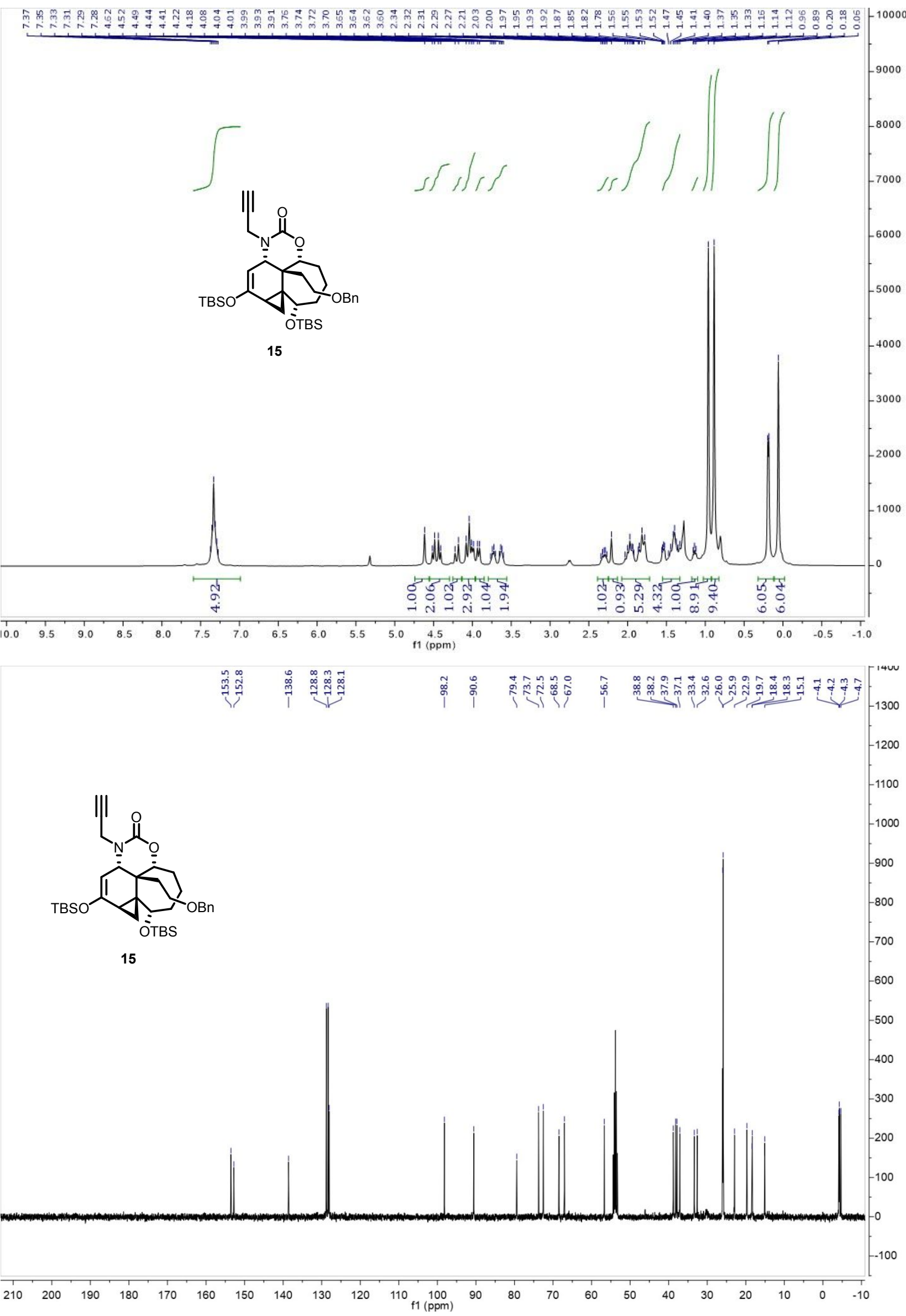



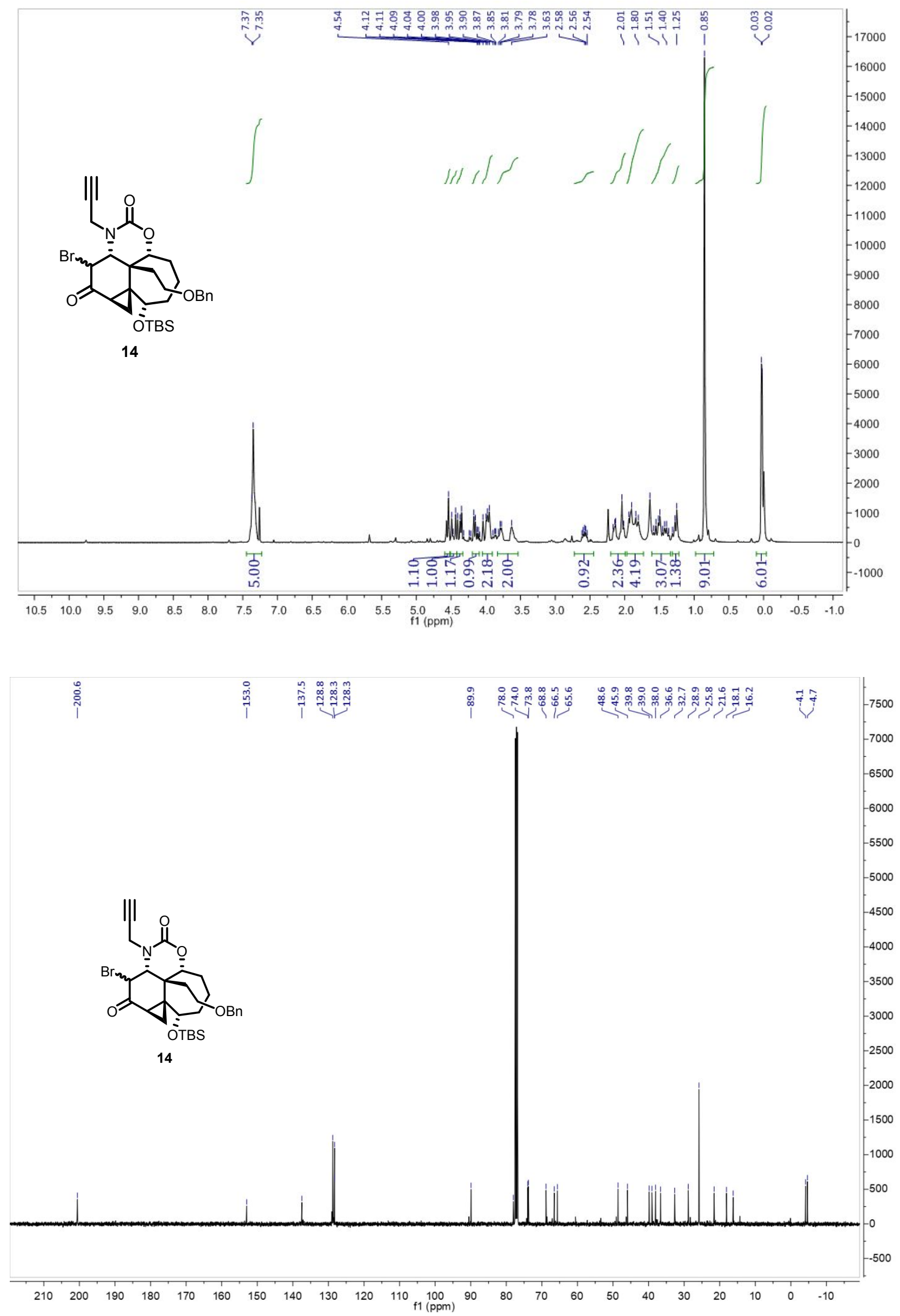


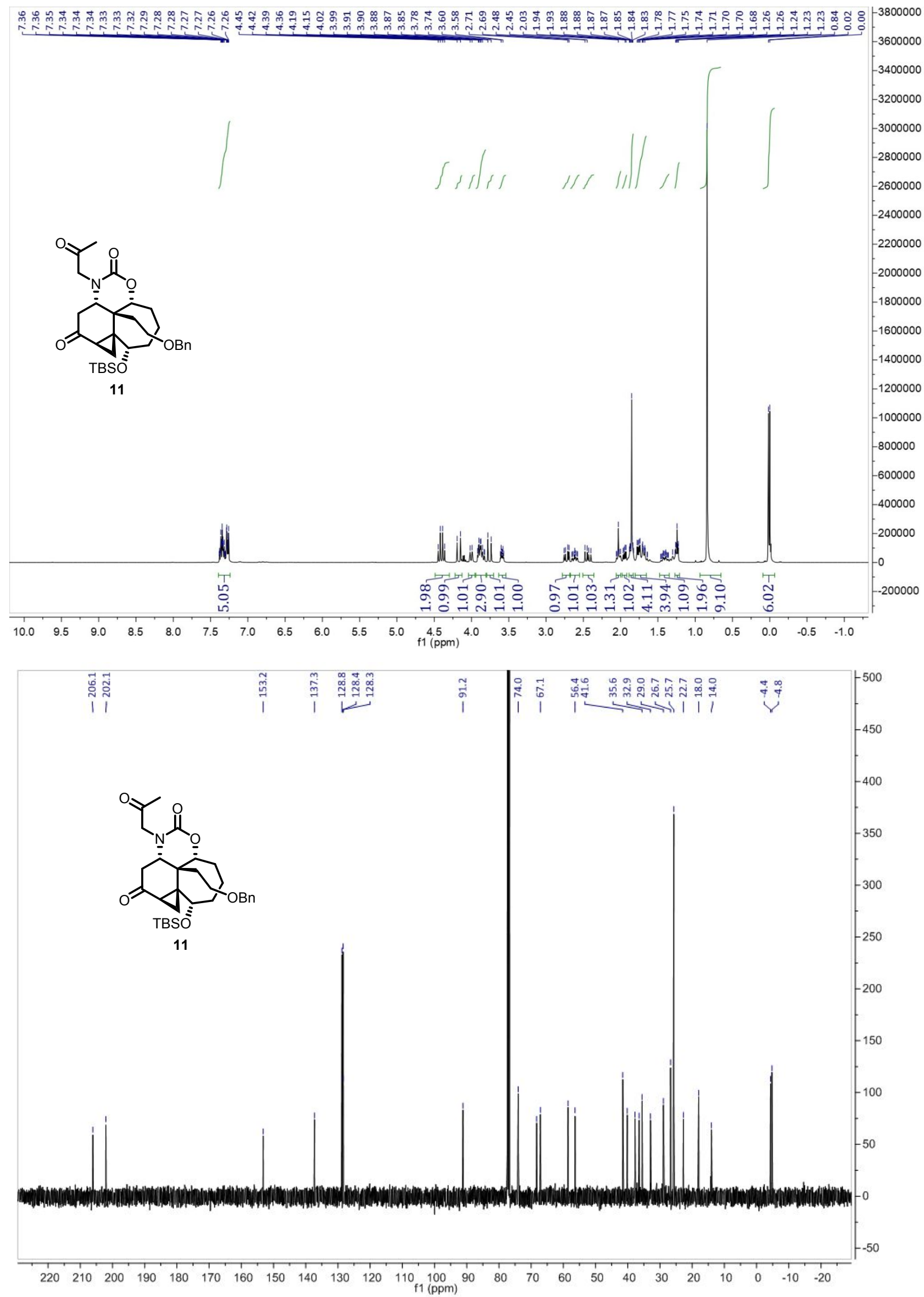



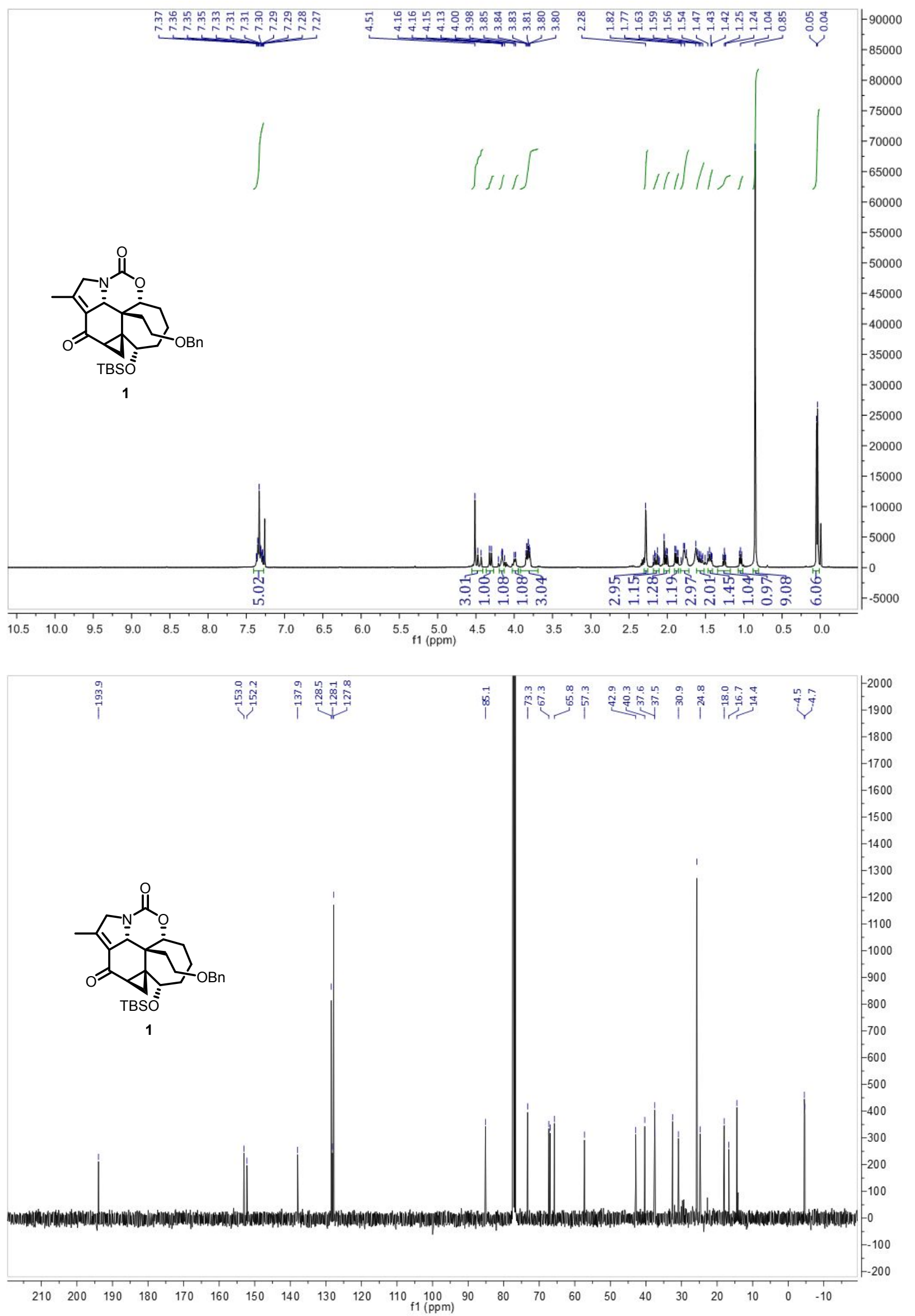